\title{
Ormanların su üretim hizmetine yönelik yeni planlama yaklaşımı
}

New planning approach for the management of forests towards water production service

\section{Mehmet ÖZDEMIR ${ }^{1}$ \\ Yusuf SERENGİL ${ }^{2}$ \\ İbrahim YURTSEVEN ${ }^{2}$ (ID \\ Muhittin INAN ${ }^{2}$ (D) \\ Pınar PAMUKÇU ALBERS 3 \\ Celal TONBUL ${ }^{1}$}

\author{
${ }^{1}$ Marmara Ormanc1lık Araștırma Enstitüsü \\ Müdürlüğü, İstanbul \\ 2 İstanbul Üniversitesi- Cerrahpaşa, Orman \\ Fakültesi, İstanbul \\ ${ }^{3}$ Doğa Koruma Merkezi, Ankara
}

Sorumlu yazar (Corresponding author) Mehmet ÖZDEMİR

mehmetozdemir@ogm.gov.tr

Geliş tarihi (Received)

18.02.2020

Kabul tarihi (Accepted)

17.05.2020

Sorumlu editör (Corresponding editor)

Şükrü Teoman GÜNER

stguner@gmail.com

Atıf (To cite this article): ÖZDEMIR, M, SERENGIL, Y, YURTSEVEN, İ, INAN, M, PAMUKÇU ALBERS, P , TONBUL, C . (2020). Ormanların su üretim hizmetine yönelik yeni planlama yaklaşımı. Ormancilık Araşıtırma Dergisi , 7 (2), 162-178

DOI: https://doi.org/10.17568/ogmoad.690985

Creative Commons Atıf Criuretilemez 4.0 - Uluslararas Lisansı ile lisanslanmıştır.

\section{Öz}

Dünya genelinde geçen yüzyıl içinde gerçekleştirilen deneysel havza çalışmaları biyokütle ile su verimi arasındaki negatif korelasyonu ortaya koymuştur. Fakat sadece bu negatif korelasyon dikkate alınıp önemli detaylar göz ardı edildiğinde "orman ne kadar şiddetli aralanır veya kesilirse o kadar yüksek seviyede su verimi artırılabilir" şeklinde yanlış bir algı oluşmaktadır. Makalede bu yaklaşımın neden terk edilmesinin gerektiği açıklanmakta ve su üretim amacına yönelik yeni orman planlama paradigması ortaya konulmaktadır. İklim değişikliği ve benzer riskler dikkate alınarak, su üretim amaçlı orman planlama, havza planlama ile eşgüdüm içinde, akarsu kıyı ekosistemlerinin kapasitesini üst düzeye taşıacak şekilde iyi yönetim uygulamaları prensipleri çerçevesinde planlamaya konu olmalıdır. Bu sonuca ulaşmak için 3 temel yaklaşım ve veri kaynağı benimsenmiştir: (1) Meta analiz, (2) Proje sonuçları ve (3) Marmara Bölgesi kapsamında ön değerlendirme. Orman planlamada havza bazında entegrasyonu, iklim değişikliğine uyum ve akarsu kıyı ekosistemlerinin planlamaya aktarılması için planlama öncesi Havza Hidrolojik Değerlendirme Raporu (HDR) ve Dere Kıyısı Ekosistemleri Yönetim Planları (DKYP) hazırlanmalıdır. Bu yaklaşımla fonksiyonel planlamada su üretimi ve toprak koruma fonksiyonları birer üst planlama fonksiyonu mantığıyla tüm ormanlara ve ormancılık faaliyetlerine dahil edilmiş olacaktır.

Anahtar kelimeler: Orman yönetimi, su üretimi, toprak koruma, iklim değişikliğii.

\begin{abstract}
During the past century, the experimental catchment studies around the globe revealed the negative correlation between biomass and water yield. Unfortunately, if the assessment relies solely on this negative relationship then a biased perception arises stating that "water yield increases proportionally as the forest cover decreases with cuttings". This paper explains why this perception should be changed and suggests a new forest planning paradigm. Taking into account climate change and similar risks, forest planning for the objective of water production should go parallel with watershed planning using methods and principles that will boost the capacity of riparian ecosystems with the best management practices". To come up with this conclusion we used three major data sources and approaches. These are; (1) Metaanalysis, (2) Project results and (3) Initial assessment for Marmara region. The relevant project outputs for the last 10 years points out the need for integration with watershed based planning, climate adaptation and the riparian ecosystems to the forest planning processes. To realize this, a Hydrologic Assessment Report (HAR) and Riparian Ecosystems Management Report (REMR) should be prepared prior to forest planning process. With this approach, we think that water production and soil conservation functions will be incorporated into whole forest areas and forestry activities as an upper level planning function.
\end{abstract}

Keywords: Forest management, water production, soil conservation, climate change. 


\section{Giriş}

Orman ekosistemlerinin çoklu fonksiyonları dünya ormancılık çevrelerinde 1960'lı yıllarda telaffuz edilmeye başlanmış, ülkemize ulaşıp orman amenajman planlarına entegre edilmesi çabaları ise 2000'li yılları bulmuştur (Özhan, 2004). Artık orman planlama ile ilgili mevzuat ve dokümanlarda hidroloji, su koruma, toprak koruma ve erozyon kontrolü kelimelerine rastlanmaktadır. Fakat bu kavramların doğru kullanımı ve amenajman planlarına gerçek anlamda entegrasyonu hala gerçekleşememiştir. Bunun temel nedeni, ormancılık eğitiminde su ve toprak koruma konularının arka plana itilmesi ve bunun bir sonucu olarak Orman Teşkilatında konunun yeterince sahiplenilmemesi ve hala silvikültür temelli 19. yüzyıl nostaljik ormancılık doktrinine sadık kalınmasıdır.

Ülkemizde son 10 yıl içinde birbirini tamamlayıc1 nitelikte gerçekleştirilmiş olan proje bulguları; orman planlamada havza bazında entegrasyonu, iklim değişikliğine uyumu ve akarsu kıyı ekosistemlerinin planlamaya aktarılması gerektiğini ortaya koymaktadir.

Makalenin amac1, su üretiminin ne olduğu ve orman planlamaya nasıl dahil edilmesi gerektiği ile ilgili uluslararası bilimin geldiği son noktayı ortaya koymaktır. HDR, DKYP ve tüm planlama sürecinde ihtiyaç duyulabilecek kriter ve göstergeler proje ve meta analiz bulgularının yorumlanması ile geliştirilmiş ve makalede sunulmuştur.

Havza kavramı basitçe yağışı akışa dönüştüren bir sistem olarak alg1lanabilir (Serengil, 2013). Sistemin sürdürülebilir yönetim sayesinde iyi yönde gelişiyor olması, dış etkenlere karşı direncinin yüksek olması; çıktı olarak algılanabilecek başta su olmak üzere ekosistem hizmetlerinin de sürdürülebilir olması anlamına gelmektedir. Dolayısıyla istenen seviyede ekosistem hizmeti üreten, iklim değişikliği ve benzeri diş etkenlere karşı dirençli havzalar günümüzde ve gelecekte toplumun refahı için gereklidir.

“Havza Yönetimi” bir havzadaki doğal kaynakların planlanması ve sürdürülebilir yönetimini kapsayan bir süreçtir (Özhan, 2004). İklim değişikliği ve benzeri antropojenik etkiler doğal kaynaklar üzerinde ciddi baskı oluşturmakta ve sürdürülebilir yönetimlerini zorlaştırmaktadır. İster doğala yakın (koruma orman1, dalyan vb.), isterse tümüyle insan etkisi altında (tarım, mera vb.) olsun ekosistemlerin işleyişlerinin belli bir düzen ve yapısı vardır ve bunların korunması gerekmektedir. Ekosistem hizmetlerinin, başta hidrolojik olanlar olmak üzere, sürekli ve üst düzeyde sağlanması havza yönetiminin başlıca araştırma konularını oluşturmaktadır.

İklim değişikliği ile mücadele süreci genellikle iki ana başlık altında ele alınmaktadır; azaltım ve uyum (Serengil ve ark., 2018). Orman ekosistemlerinin azaltımdaki rolü son yıllarda müzakere ve araştırmalara yoğun biçimde konu olmuş (LULUCF, REDD+, vb.), karbon tutum ve salımı ile ilgili başta IPCC (Intergovernmental Panel on Climate Change) olmak üzere birçok kurum tarafından metot ve katsayılar geliştirilmiştir. Konunun uyum (adaptasyon) boyutu önceleri daha arka planda kalmışken son IPCC Değerlendirme Raporu (IPCC, 2014)'nda ifade edildiği gibi, ısınmanın en iyimser tahminle $1,5^{\circ} \mathrm{C}$ 'nin üzerinde gerçekleşeceğinin (yüzyılın sonu itibariyle) anlaşılması ile iklim değişikliği müzakereleri ve bilimsel çalışmalarda "uyum" konusu ön plana çıkarılmıştır.

Dünya genelinde ekosistemler insan kaynaklı çeşitli etkenler nedeniyle sürekli artan biçimde bask1 altındadır (Sicard ve ark., 2016). Bu süreç içerisinde nüfus artışına ve yoğunlaşmasına paralel biçimde ekosistem hizmetlerine talep artmakta, biyoçeşitlilik ve benzeri hizmetlerin sürdürülebilirliği risk altına girmektedir. İklim değişikliğinin de çeşitli şekillerde (yangın frekansının artması, böcek zararları, kuraklığa dayalı ölümler vb.) bu baskıyı artırması ve ekosistemlerin işleyişini, yapısını ve bileşimini etkilemesi birçok bölge için söz konusu olabilecektir. Ülkemizin \%30'a yakın bölümünü kaplayan orman alanlarının bu yönde daha etkin planlanması hem iklim değişikliği ile mücadele, hem de ekosistem hizmetlerini daha üst seviyede ve sürdürülebilir şekilde sağlanması bakımından önemlidir.

Tüm bu baskı ve etkenlere karşı havza ve orman planlamasını daha etkin biçimde gerçekleştirmek yönünde son yıllarda "direnç" (İngilizce: resiliency) kavramı ortaya atılmıştır (Biggs ve ark., 2012). Bu kapsamda "direnç" kavramı ekosistemin etki ve değişime karşı önceki sağlıklı durumuna dönme kapasitesi olarak tanımlanabilir (Rammer ve Seidl, 2015). Bir orman ekosisteminin diş etkenlere karŞ1 direncini belirleyen özellikleri; biyoçeşitliliği, meşcere yapısı, geçmişte maruz kaldığ 1 etkiler ve ormancılık uygulamalarıdır (fidan orijini, yangın, tür seçimi, odun üretimi, yol inşaatı vb.). Tüm bu etkenler ormanın insan eli ile nasıl idare edildiğine bağlıdır. Bir başka deyişle ormanın planlanma ve işletilme şekli onun direnç seviyesini belirler. Dolayısıyla ormana her müdahalede temel amaçlardan biri; dış etkilere karşı direnci artırıcı bir meşcere yapısının elde edilmesi olmalıdır. Bu, yangın konusunda yangına dirençli türlere öncelik verilmesi, fırtına zararına karşı dirençli türlerle daha sık meşcereler oluşturulması, böcek zararı söz konusu ise 
tür çeşitliliği yüksek meşcerelerle olabilir.

Öte yandan son y1llarda adaptif orman amenajman1 ve planlama kavramları da sıkça gündeme gelmektedir. Aslında ortaya çıkışı 20. yüzyılın başları ve çıkış yeri de işletmelerde sürekli gelişim nosyonudur (Stankey ve ark., 2005). Doğal kaynak yönetimine aplikasyonu ise yüzyıl sonunu bulmuştur. Yine Stankey ve ark. (2005)'e göre ilk ortaya çıkan tanımlamalarında vurgulanan özellikleri;

- Tasarımın ve deneysel çalışmaların önemi,

- Farklı karar süreçlerinin sonuçlarından dersler çıkarılması,

- Veri ile uygulama arasındaki bağlantının önemi,

- Farklı kaynaklardan derlenen verilerin entegrasyonu,

- Bu süreci yönetecek kurumsal yapıdır.

K1saca özetlenecek olursa adaptif kaynak planlama derken; değişen sosyal, ekonomik ve ekolojik şartlara en yüksek uyum seviyesini yakalamak için olası etki, sonuç ve diğer tüm verilerin toplanıp analiz edildiği ve bu analiz sonuçlarına göre amenajman ve planlama yaklaşımlarının gelen her önemli veri ile geliştirildiği bir kaynak yönetimi konseptinden söz edilmektedir.

Adaptif planlama ve direnç kavramlarının orman planlamaya kesin biçimde uyarlanması önemli bir önceliktir ve su üretim fonksiyonu ile doğrudan ilişkilidir.

$\mathrm{Bu}$ çalışma için, Teşekkür bölümünde verilen OGM projesi, ayrıca Tübitak destekli projelerin ((Serengil ve ark. (2018-2021), Serengil ve ark. (2012-2015), Serengil ve ark. (2007-2010)) bulgularından yararlanılmıştır.

\section{Materyal ve Yöntem}

Metodoloji 3 ana bileşenden oluşmaktadır. Ormanların su üretim fonksiyonu ile ilgili araştırma bulguları bir meta analizi ile ele alınmış, bunu arazi ölçmeleri ile ilgili bulgular desteklemiş ve son olarak da Marmara Bölgesi özelinde konu ele alınmıştır.

\subsection{Meta-analiz}

Meta analizinde amaç orman planlamaya su üretim ve yakından ilişkili erozyon kontrol fonksiyonlarının dahil edilmesinde temel ilkelerin ortaya konulmasıdır. Bunun için ulusal ve uluslararası literatür derlenmiş ve ortaya özet sonuçlar çıkarılmıştır. $\mathrm{Bu}$ sonuçların orman planlamaya su üretim fonksiyonunu dahil etme yaklaşımını belirlemede büyük katkı yapması beklenmektedir. Bu amaçla meta analizinde belirlenen araştırma soruları şunlar olmuştur;

- Su üretimini düzenleme amaçlı ormancılık uygulamaları nelerdir?

- Bu ormancilık uygulamalarının etki seviyesi nedir?

- Su üretimi ile toprak koruma etkileşimi ne yönde gerçekleşmektedir?

- Ekolojik faktörler su üretiminde ne seviyede ve ne yönde etkilidir?

- Ormancılık uygulamaları; arazi kullanımı, topoğrafya ve yağış koşulları ile karşılaştırıldığında ne seviyede etkilidir?

- İklim değişikliği ve diğer antropojenik faktörler su üretiminde ne seviyede riskler oluşturmaktadır?

\subsection{Arazi ölçmeleri}

Marmara Bölgesi ormanları 1lıman kuşağa özgü geniş yapraklı meşe, kayın ve gürgen ağırlıklı türlerin saf ve karışık meşcerelerinden oluşmaktadır. Bölgede yer alan iğne yapraklı meşcereler ise sonradan ağaçlandırma yoluyla getirilmiş karaçam ve sahil çamı ağırlıklı ekosistemlerdir. Proje kapsamında hidrolojik yapıyı ve etkili parametreleri ortaya koymak amaçlı olarak arazide ölü örtü, toprak, akarsu koridoru ve su kalitesi ölçümleri, vejetasyon ölçümleri ve yaprak yüzey indeksi (yaprak alan indeksi) (LAI) ölçümleri yapılmıştır. Marmara Bölgesi'nde İstanbul-Belgrad ormanları ve Şile, Kırklareli-İ̆gneada ve Bursa ili çevresinde yapılan ölçümler aşağıdaki Tablo 1'de verilmiştir.

Ağaç çap ve boyları meşcere özelliklerini temsil eden rastgele bir örnekleme alanında $400 \mathrm{~m}^{2}$ büyüklüğündeki dairesel şekilli örnekleme alanı içerisinde gerçekleştirilmiştir. LAI ölçümleri, toprak, kuadrat (çerçeve) ve ölü örtü örneklemeleri merkeze

Tablo 1. Arazi ölçümleri

Table 1. Field measurements

\begin{tabular}{lccccc}
\hline Ölçümler & $\begin{array}{c}\text { Belgrad } \\
\text { ormanları }\end{array}$ & Şile & $\begin{array}{c}\text { Kirklareli } \\
\text { (İğneada) }\end{array}$ & Bursa & $\begin{array}{c}\text { Toplam ölçüm } \\
\text { sayısı }\end{array}$ \\
\hline Toprak örnekleme ve ölçümleri & $55 \times 4$ & $8 \times 4$ & $16 \times 4$ & $10 \times 4$ & 356 \\
Akarsu koridoru ve su kalitesi ölçümleri & 33 & 19 & 14 & 1 & 67 \\
Vejetasyon ölçümleri & $55 \times 4$ & $8 \times 4$ & $16 \times 4$ & $10 \times 4$ & 356 \\
Yaprak yüzey indeksi ölçümleri & $55 \times 4$ & $25 \times 4$ & $16 \times 4$ & $10 \times 4+5$ & 429 \\
\hline
\end{tabular}


uzaklıkları 11,28 m (yarıçap) olacak şekilde kuzey, güney, doğu ve batı yönlerinden alınan 4 farklı örnekleme noktasında gerçekleştirilmiştir (Şekil 1).

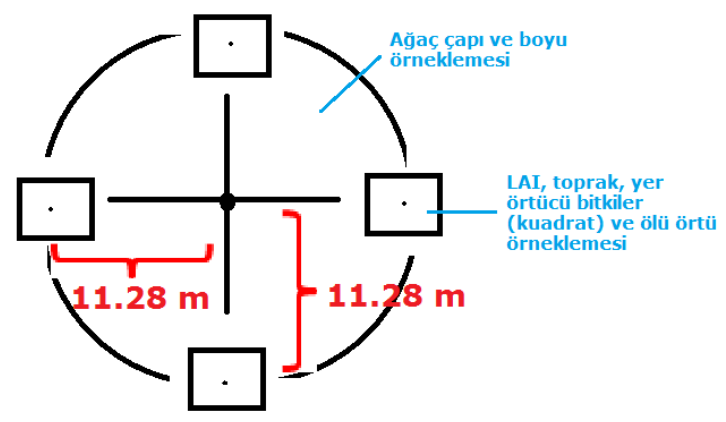

Şekil 1. Bir örnek noktasının genel görünümü

Figure 1. The general features of a sampling point

\subsubsection{Toprak örnekleme ve ölçümleri}

Farklı meşcereler altından her örnekleme noktası için dört yönde toprak örneği laboratuvarda analiz edilmek üzere alınmıştır. Topraklar kuadrat örneklemesinin yapıldığ 1 noktalardan $0-20 \mathrm{~cm}$ ve $20-40 \mathrm{~cm}$ derinlik kademelerinden alınarak örneklenmiştir.

Laboratuvar analizlerinde toprakların bazı fiziksel özellikleri (2 mm'nin üzerindeki inorganik parçaların analizi, ekivalan çapları $2 \mathrm{~mm}$ ve altında olan tane boyutu sınıflarının oransal analizi (toprağın tekstür analizi), hacim ağırlığı, erozyon duyarlılığ ve organik madde miktarı belirlenmiştir. Toprakların ince kısımları elde etmek için yapılan tekstür analizi için Bouyoucos Hidrometre Yöntemi (Bouyoucos, 1936) uygulanmıştır. Hacim ağırlığg, içerisinde boşluklu yapı barındırabilen doğal yapısı bozulmamış belirli bir hacimdeki silindir örneği içerisindeki toprağın ağırlığı olarak hesaplanmaktadir.

Toprakların organik madde miktarları ise Walkley-Black Yöntemi (Walkley ve Black, 1934) ile belirlenmiştir. Toprak erozyon duyarlılığı değeri yaygın kullanılan erodibilite indeks değerlerinden birisi olan Middleton'un Dispersiyon Oranı eşitliği (Middleton, 1930) ile belirlenmiştir. Bu eşitlik topraklardaki doğal agregatların su ile temasa geldiğinde çözülme (dispersleşme) derecesini gösteren bir orandır. 2 mm'lik elekten geçirilmiş toprağın hiçbir mekanik ve kimyasal dispersleşmeye tabi tutulmadan saf suda çalkalanmasıyla elde edilen toz+kil miktarının, topraktaki mevcut gerçek toz+kil miktarına oranı şeklinde hesaplanmaktadır. Bu eşitlik aşağıda gösterilmiştir:

$$
\mathrm{DO}=\frac{(\% \text { toz }+\% \text { kil }) \text { disperslerștirilmemiş }}{(\% \text { toz }+\% \text { kil }) \text { dispersleştirilmiş }}
$$

$\mathrm{Bu}$ orandaki değer ne kadar büyükse toprağın erozyona duyarlılığı o kadar fazla yani erozyona yakınlığ 1 ifade etmektedir. Bu indekse göre toprakların erozyona dayanıklılık sınırı \%15 olarak verilmiştir. Diğer bir deyişe \%15'ten büyük dispersiyon oranı değerleri erozyona yatkınlığ $1, \% 15$ 'ten küçük dispersiyon oranı değerleri ise erozyona dayanıkl1lığ 1 ifade etmektedir.

\subsubsection{Akarsu koridoru ve su kalitesi ölçümleri}

- Akış hızı (m/sn),

- Kanal genişliği (m),

- Dolu kanal yüksekliği (m),

- Su derinlikleri (cm),

- Eğim (\%),

- D50 (su kütlesinde bulunan toplam sedimentin boyutsal olarak medyan değeri) $(\mathrm{cm})$,

- Sediment boyutu (cm),

- Su kalitesi verileri olarak elektriksel iletkenlik, pH, bulanıklık, sıcaklık, çözünmüş oksijen konsantrasyonu değerleri akarsularda ölçülmüştür. Bu değişkenlerden sıcaklık, pH, elektriksel iletkenlik ve çözünmüş oksijen değerleri WTW multiline P4 portatif cihazı ile bulanıklık değerleri ise WTW Portable turbidity meter Turb ${ }^{\circledR}$ 355 cihazı ile belirlenmiştir.

- Sediment birikimin ve/veya odunsu moloz birikiminin olup olmadığ1

- Sel-taşkın oluşumunun mümkün olup olmadığ1

- Askıda katı madde miktarı gravimetrik yöntem yardımıyla hesaplanmıştır.

\subsection{3. Ölü ve diri örtü ölçümleri}

Örnekleme noktalarında dört yönde ölü örtü kalınlığ1 ölçülmüştür.

- Örnekleme noktalarında ölü örtü ve diri örtü çerçeve $(50$ x $50 \mathrm{~cm})$ örnekleri alınmıştır. Bu örneklerin hem yaş hem de $105^{\circ} \mathrm{C}$ 'deki fırın kurusu ağırlıkları laboratuvarda ölçülmüştür. Fırın kurusu ağırlık için laboratuvara getirilen gövde ve dal örnekleri 96 saat, yapraklar ise 24 saat süre ile kurutma fırınında bekletilmiştir.

- Örnekleme noktalarında diri örtü için çerçeve örnekleri alınırken tür sayımı yapılmıştır.

- Farklı kapalılık ve farklı meşcerelere sahip olan örnekleme noktalarında ağaçların yerden 1,30 m yüksekliğindeki çapları ölçülmüştür.

- Dikili kuru ve/veya devrik ağaçların olup olma- 
dığ 1 arazide tespit edilmiştir.

- Meşcere tabaka durumu ve gelişme çağ da arazide belirlenmiştir.

\subsubsection{Yaprak yüzey indeksi ölçümleri}

Yaprak yüzey indeksi (LAI) özellikle orman alanlarındaki yapraklanma durumunu modellemede önemli bir değişken konumundadır ve birim alana düşen yaprakların kapladığı alanın birim alana oranı olarak tanımlanabilmektedir. LAI ölçümleri genellikle ağaçların kesilerek tüm yaprakların örneklenmesiyle doğrudan şekilde hesaplanabileceği gibi allometrik modeller ve optik ölçümler gibi metotlar da kullanılmaktadır. LAI ölçümleri proje kapsamında optik metotla ölçülmüştür. Üzerinde yarı-küresel (balıkgözü) lens takı1ı görüntü almaya yarayan cihazlarla belirli noktalardan alınan örnekler sayesinde alanın ölçekli biçimde yapraklanma durumu saptanabilmektedir. Farklı kapalılık ve farklı meşcerelere sahip olan örnekleme noktalarında (İstanbul Belgrad Ormanı), Bursa, Şile ve Kırklareli) LAI ölçümleri yapılmıştır.

Farklı meşcereler altında yapılan LAI ölçümlerine ek olarak; 2 yıl boyunca Marmara Bölgesi'nde belirlenen geniş yapraklı ve iğne yapraklı ormanlarda geçici ve kalıcı noktalarda LAI ölçülmüş ve zamansal değişimi belirlenmiştir. Kalıcı noktalarda haftalık ölçümler yapılmıştır. Ölçüm sonuçları, LAI ölçümlerindeki zamansal değişimleri ortaya koymak için kullanılmıştır. Proje kapsamında LAI ölçümleri, CID CI 110-120 Digital Plant Canopy Imager cihazıyla yapılmış ve aşağıdaki eşitlikle hesaplanmıştır:

LAI = Yaprak alanı $\left(\mathrm{m}^{2}\right) /$ Örnek yüzey alanı $\left(\mathrm{m}^{2}\right)$

LAI ölçümleri ile intersepsiyon arasındaki ilişki regresyon analizi ile belirlenmiştir.
Ayrıca uydu görüntülerinin çeşitli bantlarının matematiksel kombinasyonları ile elde edilen Bitki Örtüsü İndeksi veya yeşillik (vejetasyon) indeksinin, proje kapsamında farklı dönemlerde ölçülen LAI ölçüm değerleri ile arasındaki ilişkiyi bulabilmek amacıyla kullanımı en yaygın olan indekslerden "Normalize Edilmiş Vejetasyon İndeksi (the Normalized Difference Vegetation index-NDVI)" hesaplanmıştır. NDVI, Erdas IMAGINE yazılımı Kontrolsüz Sınıflandırma - NDVI aracı kullanılarak SPOT 2012 uydu görüntüleri üzerinden yapılmıştır. NDVI, aşağıdaki formüle göre hesaplanmaktadir.

$$
\mathrm{NDVI}=(\mathrm{NIR} / \mathrm{RED}) /(\mathrm{NIR}+\mathrm{RED})
$$

NIR: Yakın kızılötesi ve RED: Kırmızı bant spektral yansıma ölçüsüdür.

Proje kapsamında ölçülen LAI ölçüm değerleri SPOT 6 uydu görüntüsü ile hesaplanan NDVI değerleri ile karşılaştırılmıştır. Böylece LAI ölçüm değerlerinin ve hatta intersepsiyonun uydu görüntüleri ile hesaplanabilme olasılığ 1 test edilmiştir.

Ayrica belirlenen 48 alt havzanın su verimlerini değerlendirebilmek için Tablo 2'de verilen meteoroloji istasyon yıllık ortalama yağış verileri Ters Mesafe Ağırlıklı Enterpolasyon Yöntemi (Inverse distance weighted-IDW) ile bölgeye enterpole edilmiştir.

\subsection{Marmara Bölgesi hidrolojik etüdü}

Marmara Bölgesi'nde Devlet Su İşleri (DSİ)'nin Akım Gözlem İstasyonlarının uzun yıllar akış ölçtüğü (en az 10 y1l) (DSİ, 2012) baraj, göl ve göletler belirlenmiş ve havzalar ArcGIS yazılımı kullanılarak Coğrafi Bilgi Sistemleri (CBS) teknikleri ile topografik haritalardaki dere ve eşyükselti eğrileri yardımıyla çıkartılmıştır (Şekil 2).

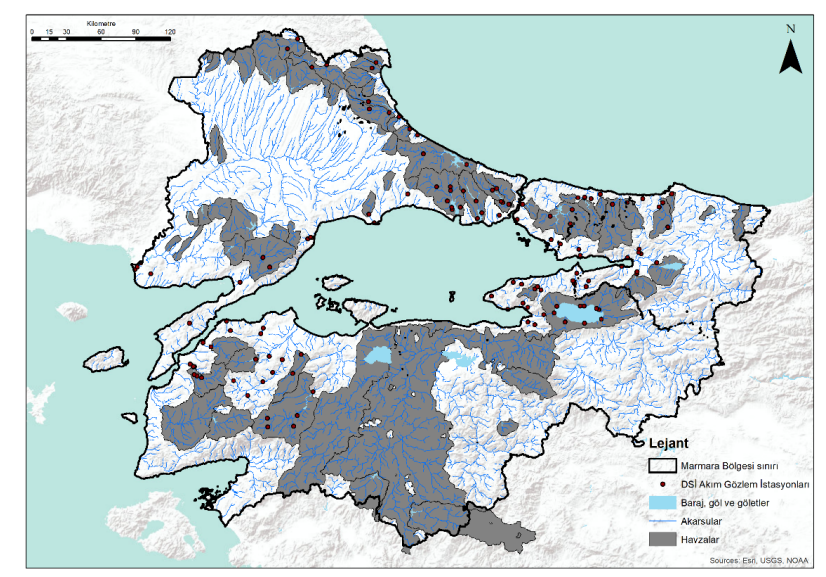

Şekil 2. Marmara Bölgesi arazi örnekleme noktaları ile baraj ve göl havzaları

Figure 2. Field sampling points and reservoir and lake watersheds in Marmara Region 
Marmara Bölgesi'nde toplam 48 baraj/göl alt havzasının alanları 17 ila $969 \mathrm{~km}^{2}$ arasında değişmektedir, ancak bu havzaların \%80'inin alanı 20 ila $200 \mathrm{~km}^{2}$ arasında değişmektedir. Marmara Bölgesi Meriç-Ergene, Susurluk, Sakarya ve Ege ana nehir havzaları ile çakışmaktadır. $\mathrm{Bu}$ ana havzalardan bağımsız olarak bakıldığında, yani bölge olarak düşünüldüğünde aslında doğal ve yapay göl havzalarının ne denli önemli bir alan kapladığı net biçimde görülmektedir.

\section{Bulgular}

\subsection{Meta-analiz}

Ormanların su üretiminde, su verimi, su kalitesi, su rejimi ve akış değişkenliğini dikkate almak gerekirken; toprak korumada ölü örtü, arazi kullanımı ve vejetasyon başlica önemli parametrelerdir. Ormanların su üretimi ve toprak koruma fonksiyonlarına ilişkin ulusal ve uluslararası literatür incelenmiş ve sonuçlar aşağıda özetlenmiştir. Buna göre ormana yapılan ağaç kesimi ve aralama müdahaleleri ilgili olarak (Serengil ve ark., 2007);

- Müdahaleye karşı hidrolojik tepki başta akış miktarı ve rejimi olmak üzere çok değişken olup çoğu zaman tahmin edilmesi olanaklı değildir,

- Müdahaleye karşı hidrolojik tepki ortalama ya- ğ1ş ve söz konusu yıldaki yağışla yakından bağlantılıdır.

- Akış rejimindeki değişimler müdahale sonrası infiltrasyon ve evapotranspirasyon koşulları ile doğrudan ilişkilidir.

- Ilıman kuşakta \%20’nin altında gerçekleşen aralama uygulamaları istatistik yönden anlamlı seviyede akış artışı genellikle yaratmamaktadır.

Su veriminin ağaç kesimi yolu ile ekonomik anlamda kayda değer düzeyde artırılabilmesi için yağışın belli seviyenin üzerinde gerçekleşiyor olması, ölü örtüye zarar vermeyecek hassas odun üretimi ve transport tekniklerinin kullanılıyor olması, buna karşın erozyon ve kütlesel toprak hareketi riskinin düşük seviyede olması gerekmektedir. Ülke genelinde orman alanlarının eğimli arazilerde yer alıyor olması, erozyonun yaygınlığı ve yağışın genellikle düşük olması nedeniyle bu tip bir yaklaşım pek mümkün olamamaktadır.

\subsection{Arazi ölçmeleri}

\subsubsection{Toprak, vejetasyon ve su örnekleme noktaları}

Projeler kapsamında örnek alanlarda gerçekleştirilen vejetasyon ve toprakla ilişkili bazı parametreler için ölçüm sonuçları aşağıda özetlenmiştir (Tablo 2).

Tablo 2. Arazi ölçümlerinin sonuçları. Ortalamalar ve standart sapma değerleri - toprak/vejetasyon

Table 2. Results of field measurements. Averages with standard deviation values - soil/vegetation

\begin{tabular}{|c|c|c|c|c|c|c|c|c|c|c|}
\hline \multirow[b]{2}{*}{$\begin{array}{c}\text { Alt } \\
\text { bölge }\end{array}$} & \multirow[b]{2}{*}{$\begin{array}{l}\text { Meşcere } \\
\text { türü }\end{array}$} & \multicolumn{3}{|c|}{ Vejetasyon } & \multicolumn{6}{|c|}{ Toprak } \\
\hline & & $\begin{array}{c}\text { LAI } \\
\left(\mathrm{m}^{2} / \mathrm{m}^{2}\right)\end{array}$ & $\begin{array}{c}\text { ÖÖ (ton } \\
\text { kuru } \\
\text { madde/ } \\
\text { ha) }\end{array}$ & $\begin{array}{c}\text { DÖ } \\
\text { (ton kuru } \\
\text { madde/ha) }\end{array}$ & $\begin{array}{l}\text { Permea- } \\
\text { bilite } \\
\text { (cm/saat) }\end{array}$ & $\mathrm{pH}$ & $\begin{array}{c}\mathrm{EI} \mu \mathrm{S} / \\
\mathrm{cm}\end{array}$ & $\begin{array}{l}\text { Org. } \\
\text { madde } \\
(\%)\end{array}$ & $\begin{array}{l}\text { Kil } \\
(\%)\end{array}$ & $\begin{array}{c}\text { Erozyon } \\
\text { duyarlılığ } 1\end{array}$ \\
\hline \multirow{4}{*}{ 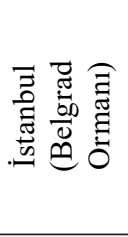 } & Yapraklı & $\begin{array}{c}1,01 \pm \\
0,99\end{array}$ & $\begin{array}{c}10,60 \pm \\
8,69\end{array}$ & $\begin{array}{c}0,49 \pm \\
1,06\end{array}$ & \multirow{4}{*}{$\begin{array}{c}67,9 \\
\pm \\
101,6\end{array}$} & \multirow{4}{*}{$\begin{array}{c}5,68 \\
\pm \\
1,05\end{array}$} & \multirow{4}{*}{$\begin{array}{c}235,56 \\
\pm \\
126,65\end{array}$} & \multirow{4}{*}{$\begin{array}{c}5,02 \\
\pm \\
1,80\end{array}$} & \multirow{4}{*}{$\begin{array}{c}10,83 \\
\pm \\
7,77\end{array}$} & \multirow{4}{*}{$\begin{array}{c}13,29 \\
\pm \\
10,05 \\
\text { Dayanıklı }\end{array}$} \\
\hline & & $1,69 \pm$ & $14,54 \pm$ & $0,41 \pm$ & & & & & & \\
\hline & yapraklı & 1,12 & 10,06 & 0,38 & & & & & & \\
\hline & Karış1k & $\begin{array}{c}0,47 \pm \\
0,41 \\
\end{array}$ & $\begin{array}{c}10,88 \pm \\
4,46 \\
\end{array}$ & $2,67 \pm 4,58$ & & & & & & \\
\hline \multirow{4}{*}{$\underset{\mathscr{D}}{\stackrel{\mathscr{n}}{\Xi}}$} & Yapraklı & $\begin{array}{c}2,73 \pm \\
0,43\end{array}$ & $\begin{array}{c}13,95 \pm \\
6,92\end{array}$ & $\begin{array}{c}0,17 \pm \\
0,12\end{array}$ & \multirow{4}{*}{$\begin{array}{c}5,74 \\
\pm \\
9,71\end{array}$} & \multirow{4}{*}{$\begin{array}{c}5,12 \\
\pm \\
1,45\end{array}$} & \multirow{4}{*}{$\begin{array}{c}155,29 \\
\pm \\
24,46\end{array}$} & \multirow{4}{*}{$\begin{array}{c}7,48 \\
\pm \\
1,88\end{array}$} & \multirow{4}{*}{$\begin{array}{c}12,1 \\
\pm \\
9,11\end{array}$} & \multirow{4}{*}{$\begin{array}{c}9,22 \\
\pm \\
6,07 \\
\text { Dayanıklı }\end{array}$} \\
\hline & İğne & $2,30 \pm$ & $15,04 \pm$ & $0,57 \pm$ & & & & & & \\
\hline & yapraklı & 0,80 & & & & & & & & \\
\hline & Karış1k & $\begin{array}{c}3,30 \pm \\
0,44\end{array}$ & $\begin{array}{c}12,06 \pm \\
6,51\end{array}$ & $\begin{array}{c}0,32 \pm \\
0,24\end{array}$ & & & & & & \\
\hline \multirow{4}{*}{$\stackrel{0}{=}$} & Yapraklı & $\begin{array}{c}1,11 \pm \\
0,80\end{array}$ & $\begin{array}{c}12,03 \pm \\
5,30\end{array}$ & $\begin{array}{c}0,55 \pm \\
0,54\end{array}$ & \multirow{4}{*}{$\begin{array}{c}12,1 \\
\pm \\
4,41\end{array}$} & \multirow{4}{*}{$\begin{array}{c}5,42 \\
\pm \\
0,69\end{array}$} & \multirow{4}{*}{$\begin{array}{c}131,09 \\
\pm \\
34,33\end{array}$} & \multirow{4}{*}{$\begin{array}{c}5,48 \\
\pm \\
2,49\end{array}$} & \multirow{4}{*}{$\begin{array}{c}15 \\
\pm \\
8,38\end{array}$} & \multirow{4}{*}{$\begin{array}{c}21,32 \\
\pm \\
12,86 \\
\text { Duyarl1 }\end{array}$} \\
\hline & İğne & $0,44 \pm$ & $18,73 \pm$ & $0,28 \pm$ & & & & & & \\
\hline & yapraklı & 0,05 & 7,30 & 0,12 & & & & & & \\
\hline & Karışık & - & - & - & & & & & & \\
\hline \multirow{3}{*}{ 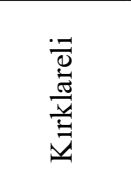 } & Yapraklı & $\begin{array}{c}0,76 \pm \\
0,55\end{array}$ & $\begin{array}{c}15,25 \pm \\
7,93\end{array}$ & $\begin{array}{c}0,34 \pm \\
0,42\end{array}$ & \multirow{3}{*}{$\begin{array}{c}32,4 \\
\quad \pm \\
24,41\end{array}$} & \multirow{3}{*}{$\begin{array}{c}4,88 \\
\pm \\
0,48\end{array}$} & \multirow{3}{*}{$\begin{array}{c}130,26 \\
\pm \\
96,0\end{array}$} & \multirow{3}{*}{$\begin{array}{c}6,28 \\
\pm \\
3,01\end{array}$} & \multirow{3}{*}{$\begin{array}{c}13,71 \\
\pm \\
6,15\end{array}$} & \multirow{3}{*}{$\begin{array}{c}0,91 \\
\pm \\
0,03 \\
\text { Dayanıklı }\end{array}$} \\
\hline & İğne & - & - & - & & & & & & \\
\hline & $\begin{array}{l}\text { уарrakı1 } \\
\text { Karışı1k }\end{array}$ & - & - & - & & & & & & \\
\hline
\end{tabular}


$\mathrm{Bu}$ sonuçlara göre Marmara Bölgesinde örneklemenin gerçekleştiği noktalar dikkate alındığında hem erozyona dayanıklı, hem de duyarlı topraklara rastlamak mümkündür. İstanbul (Belgrad Ormanı) çevresinde, Bursa ve Kırklareli'nde erozyona dayanıklı toprakların yer aldığı, buna karşın Şile'de ise erozyona duyarlı topraklara rastlandığı ortaya çıkmaktadır (Tablo 3).

Tablo 3. Arazi ölçümlerinin sonuçları. Ortalamalar ve standart sapma değerleri - akarsu kesitleri Table 3. Results of field measurements. Averages with standard deviation values - stream profiles

\begin{tabular}{|l|c|c|c|c|c|c|}
\hline \multirow{2}{*}{ Alt bölge } & \multicolumn{5}{|c|}{ Su kalitesi parametreleri } \\
\cline { 2 - 7 } & $\mathrm{pH}$ & $\begin{array}{c}\text { EI } \\
(\mu \mathrm{S} / \mathrm{cm})\end{array}$ & $\begin{array}{c}\text { Bulan1kl1k } \\
(\mathrm{NTU})\end{array}$ & $\begin{array}{c}\text { Oksijen } \\
(\mathrm{mg} / \mathrm{l})\end{array}$ & $\begin{array}{c}\text { Süspanse } \\
\text { sediment } \\
(\mathrm{g} / \mathrm{l})\end{array}$ & $\begin{array}{c}\text { Ak1ş h1z1 } \\
(\mathrm{m} / \mathrm{sn})\end{array}$ \\
\hline İstanbul (Belgrad orman1) & $7,51 \pm 0,41$ & $841 \pm 407$ & $27,4 \pm 65,4$ & $7,50 \pm 3,65$ & $0,67 \pm 0,39$ & $0,22 \pm 0,25$ \\
\hline Şile & $7,89 \pm 0,39$ & $732 \pm 568$ & $8,55 \pm 7,74$ & $5,13 \pm 2,92$ & $0,55 \pm 0,19$ & $0,23 \pm 0,18$ \\
\hline Kirklareli & $7,82 \pm 0,63$ & $335 \pm 109$ & $47,1 \pm 80,2$ & $7,58 \pm 2,13$ & $0,32 \pm 0,31$ & $0,37 \pm 0,26$ \\
\hline
\end{tabular}

Su kalitesi bakımından tüm ölçüm noktalarının sorunsuz olduğu, buna karşın İstanbul çevresinde su kalitesinin Kırklareli ve Şile'ye göre daha bozuk olduğu anlaşılmaktadır.

\subsubsection{Yaprak yüzey indeksi ölçmeleri}

Su üretimi, en basit tabiriyle yağış ve evapotranspirasyonun (ET) farkıdır. Su kaynaklarının sürdürülebilir yönetimi ve fonksiyonel orman yönetimi için bölgesel ölçekte ET ve/veya bileşenlerinin bilinmesi (ölçülmesi ve hesaplanması) gereklidir. Ampirik denklemler, arazi ölçümleri ve uzaktan algılama verileri ile birlikte çalışan birçok model ET'yi hesaplamak için geliştirilmiş ve kullanılmıştır. ET tahminlerindeki en önemli parametrelerden biri yaprak yüzey indeksi (LAI) dir. LAI ölçümleri, orman meşceresindeki su tüketimini ve ET'yi belirleyebilen anahtar bir parametredir. Ancak ET, hem zamansal, hem de mekânsal açıdan çok değişkendir. ET’nin en büyük bileşenlerinden biri de intersepsiyondur. LAI ölçümleri ve intersepsiyon arasındaki ilişki birçok ekolojik faktöre bağlıdır.

Proje kapsamında yapılan çalışmada, İstanbul (Belgrad Ormanı), Bursa, Şile ve Kırklareli'de farklı meşcereler altında yapılan LAI ölçümleri yanında 2 yıl boyunca Marmara Bölgesi'nde belirlenen geniş yapraklı ve iğne yapraklı ormanlarda kalıcı noktalarda LAI ölçülmüş ve zamansal değişimi belirlenmiştir (Şekil 3).

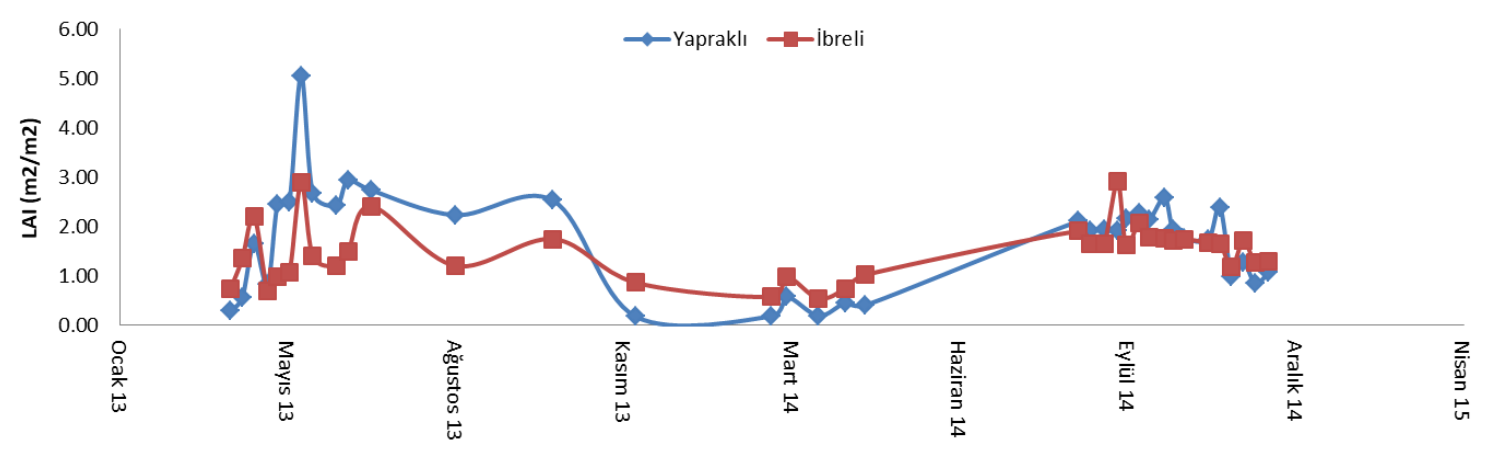

Şekil 3. Sabit noktalardan ölçülen LAI ölçüm değerleri

Figure 3. LAI values measured at permanent plots

Ölçüm sonuçları, LAI ölçümlerindeki zamansal değişimleri ortaya koymak için kullanılmıştır. Yıllık ortalama LAI ölçüm değeri, geniş yapraklı ormanlarda $1,61 \mathrm{~m}^{2} / \mathrm{m}^{2}$, iğne yapraklı ormanlarda ise $1,39 \mathrm{~m}^{2} / \mathrm{m}^{2}$ dir. Burada iğne yapraklıların daha düşük ortalama LAI ölçüm değerine sahip olmasını genellememek gerekir. Zira bu sonuçlar ölçüm yapılmış olan meşcere özellikleri ile ilgilidir. Burada önemli olan mevsimsel değişimlerdir. Yağışlı mevsimde LAI ölçüm değeri, geniş yapraklı orman- larda iğne yapraklı ormanlardan daha düşüktür. Ayrıca, sonuçlar, intersepsiyon ve LAI ölçümleri arasındaki ilişkinin, intersepsiyon ve yağış arasındaki ilişki kadar kuvvetli olmadığını göstermiştir.

Şekil 4'te görüleceği gibi yapraklı ve iğne yapraklı meşcereler arasındaki fark mayıs ayında en yüksek değerine ulaşmaktadır. Yağışın en yüksek geçekleştiği kasım-şubat döneminde ise yaprakların dökülmesi ile LAI ölçüm değeri yapraklı meşcerelerde ibrelilerin altına düşmektedir. Yaprak dökü- 
münün bölgede genellikle kasım ayının son haftası gerçekleştiği dikkate alındığında bu durum normal karşılanabilir. Nisan-ekim döneminde ise yapraklı türlerden oluşan meşcerelerin LAI ölçüm değerleri iğne yapraklilardan hep yüksek seyretmiştir.

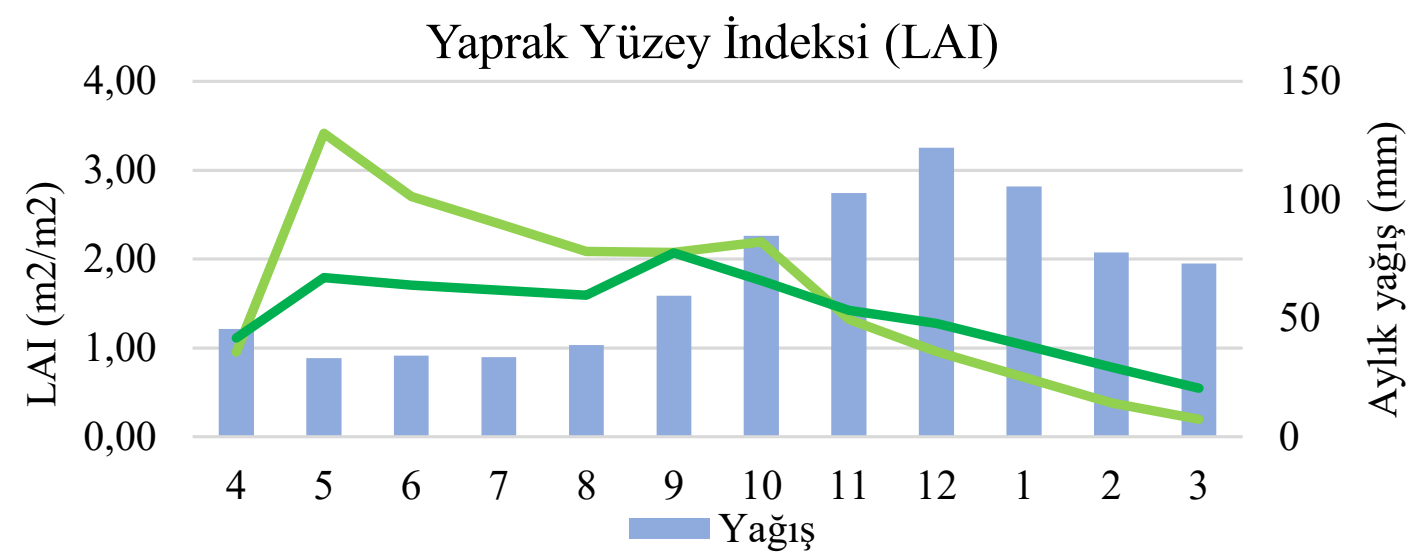

Şekil 4. Yapraklı ve iğne yapraklı orman ekosistemlerinde LAI ölçümlerinin yıl içindeki değişimi ve yağışla olan etkileşimi

Figure 4. The interannual variation of LAI measures and interaction with precipitation at broadleaved and coniferous forest ecosystems

Şekil 4'ten anlaşılacağı gibi ilkbahar ve sonbahar yağışlarının iğne yapraklı veya yapraklı meşcerelerdeki intersepsiyon değerleri önemli farklılık göstermeyecektir. Ülkemiz açısından yaygın olan aralık-mart dönemi yağışlarında ise yapraklı orman intersepsiyon değerinin daha düşük seyretmesi beklenmektedir. Fakat söz konusu dönemde sıcaklık değerlerinin de düşük olacağı ve intersepsiyonun yaz dönemi kadar yüksek olmayacağı dik-
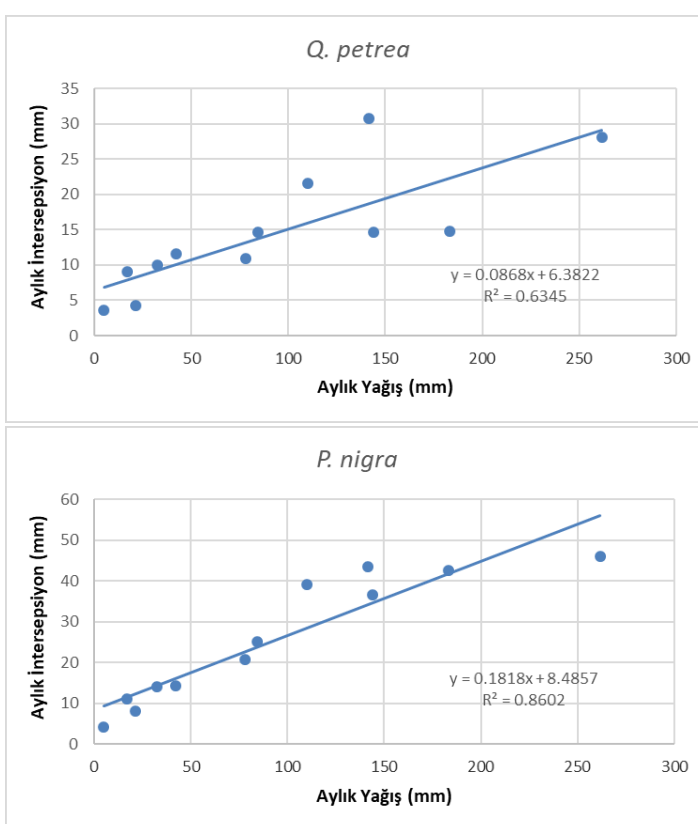

kate alınmalıdır.

LAI ölçüm değerleri intersepsiyon ile ilişkilendirildiğinde ise çok farklı bir durum ortaya çıkmaktadır. Özhan (1982) yağış ve intersepsiyon arasında doğrusal ilişkileri araştırmıştır. Özhan (1982) ile proje verileri kombine edildiğinde yağışla intersepsiyon arasında oldukça güçlü bir etkileşim görülürken intersepsiyon ile LAI ölçümleri arasında daha gevşek bir ilişki saptanmıştır (Şekil 5).
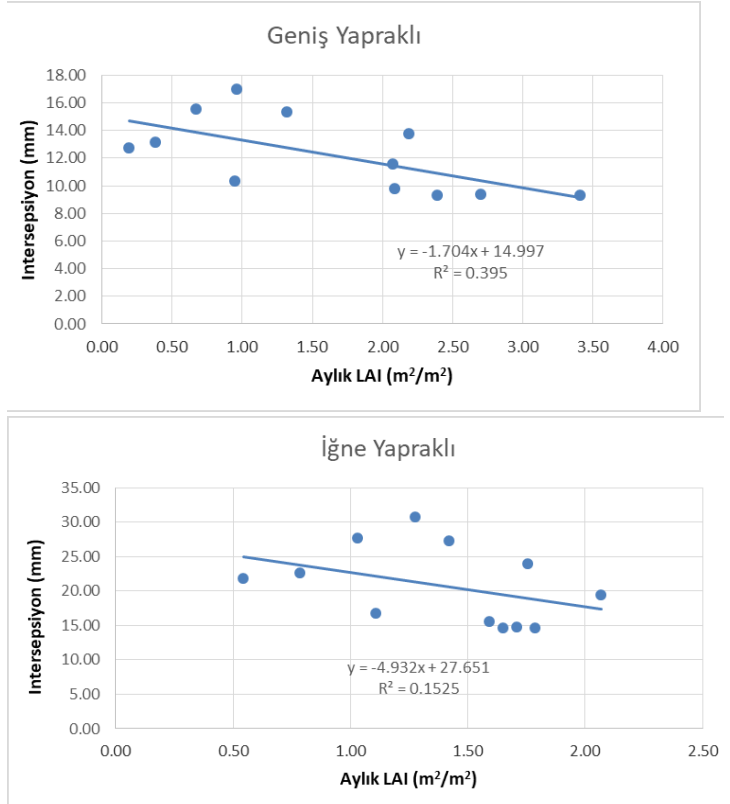

Şekil 5. Yapraklı ve iğne yapraklı orman ekosistemlerinde yağış-intersepsiyon ve intersepsiyon-LAI ölçümleri etkileşimi. Q. petrea ve $P$. nigra grafikleri Özhan (1982) verilerinden geliştirilmiştir

Figure 5. Precipitation-interception and interception-LAI measures relationship at broadleaved and coniferous forest ecosystems. First 2 graphs developed from Özhan (1982) data 
LAI'nin uzaktan algılama ile belirlenmesine yönelik bir alt çalışmada proje kapsamında farklı dönemlerde ölçülen LAI ölçüm değerleri Şekil 6 (sabit noktalarda ölçülen LAI ölçüm değerleri) grafiği sayesinde mayıs ayına enterpole edilmiş ve SPOT 2012 uydu görüntüsünden hesaplanan NDVI değerleri ile ilişkilendirilmiştir. Şekil 6'da NDVILAI etkileșimi verilmiștir. NDVI ve LAI ölçümleri arasında kuvvetli olmasa da doğrusal bir ilişki saptanmıştır.

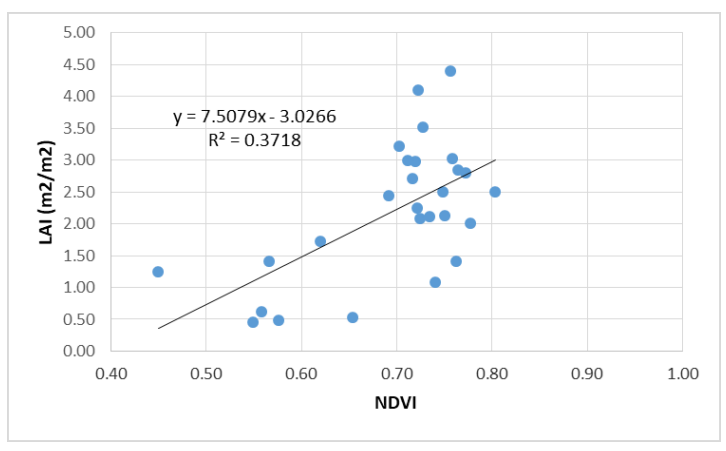

Şekil 6. Ölçülen LAI değerleri ile NDVI arasındaki doğrusal ilişki

Figure 6. Linear relationship between measured LAI values and NDVI

\subsection{Marmara Bölgesi hidrolojik etüdü}

Baraj, göl ve/veya hassas sulak alanların sürdürülebilir bir şekilde korunup kullanılabilmesi için havzalarının belirlenmesi ve ormancılık uygulamalarının bu sınırlar içinde daha hassas yapılması gerekmektedir. Orman amenajman planları bilindiği üzere her Orman İşletme Şefliği orman alanları için hazırlanmaktadır. Şeflik sınırları kimi zaman baraj, göl ve gölet havzalarını bütünüyle kapsayamamakta ya da başka bir su yüzeyinin havzasını da içine almaktadır. Böyle bir sınırda gerçekleştirilecek olan uygulama belki de barajın su miktarına ya da havzadaki su verimine hiç etki etmeyecek, farklı bir derenin kolundan farklı bir rezervuarı etkileyecektir. Özellikle baraj, göl ve/veya hassas sulak alanların çevrelerinde su üretimine yönelik yönetilecek ormanlarda, yapılacak olan müdahale havza sınırlarını esas almalı, toprak, iklim, vejetasyon ve topografyaya bağlı olarak yapılacak olan silvikültürel müdahalelerle optimal orman yapısı oluşturularak havzadaki su verimi, su miktarı ve su rejimi doğal akış karakteri sağlanmalıdır.

Bir havzadaki arazi kullanım değişiklikleri ve ormana yapılan müdahaleler, yağışın akışa dönüşümünü ifade eden akış katsayısı üzerinde rol oynamaktadır. Marmara Bölgesi'nde yapılan başka bir çalışmada (Pamukçu ve ark., 2014), DSİ Akım
Gözlem İstasyonlarında (DSİ, 2012) uzun dönem akış verisine sahip olan baraj havzalarında 1990, 2000 ve 2006 yılları için CORINE arazi sınıflandırması ile bu havzalardaki arazi kullanımı değişimleri belirlenmiştir. Uzun yıllar akım verileri, arazi kullanım değişikliklerinden dolayı artmakta ya da azalmakta olmasına rağmen, akım verileri ile arazi kullanım değişiklikleri arasında istatistiksel bir ilişki bulunamamıştır.

Marmara Bölgesinde 48 adet alt havzaya ait bazı hidrolojik ve klimatolojik parametre sonuçları Tablo 4 'te gösterilmiştir.

Tablodan görüleceği gibi akış katsayıları oldukça değişkendir. Genellikle akış katsayısını etkileyen parametreler arazi kullanımı yanında ve aslında ondan çok daha etkili biçimde ortalama eğim, havza boyutu, yağış karakteristikleri ve havza şeklidir (Pamukçu ve ark., 2016).

\section{Tartıșma ve Sonuç}

Ormanların su üretim fonksiyonu 4 temel çerçevede ele alınmalıdır (Serengil ve ark., 2012);

- Su verimi,

- Su kalitesi,

- Ak1ş değişkenliği,

- Ekstrem akışlar.

Makalede bu dört çerçeve birleștirilmiş, su üretim veya hidrolojik fonksiyon altında basitleştirilmiştir. Ekstrem akışlar maksimum ve minimum akışlar yanında ekolojik akışları da kapsamakta, akış değişkenliği ise akışlardaki yıl içi ve/veya yıllar arası değişimleri ifade etmektedir.

Proje kapsamında elde edilen bulgular Marmara Bölgesinde hem arazi kullanımı, hem de hidrolojik yapı olarak önemli farklılıkların olduğunu ortaya koymaktadır. Akış katsayıları \%22,47'den \%76,04'e kadar geniş bir aralıkta değişim göstermektedir. Bunun anlamı yağışın dörtte biri ile dörtte üçü kadar bir kısmı akarsulara ulaşmaktadır. Bu değer aralığı içinde \%50 civarı akış katsayılarının ağırlıkta olması topoğrafik olarak eğimli havzaları işaret etmektedir. Belgrad Ormanı deneysel havzalarında akış katsayısının \%20-30 aralığında değişkenlik göstermesi (Serengil ve ark., 2007; Gökbulak ve ark., 2016) bu havzaların genellikle 100 ha ve daha düşük alana sahip ve yüksek kapalılıkta

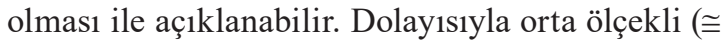
$100 \mathrm{~km}^{2}$ ) Marmara havzalarının akış katsayılarının yıllık bazda değişken olmakla beraber ortalama \%40-50 aralığında olduğu anlaşılmaktadır. Yağışın ortalama $700 \mathrm{~mm}$ civarında olduğu düşünüldüğünde ortalama su veriminin yıllık 300-350 
Tablo 4. Marmara Bölgesi baraj, göl ve/veya hassas sulak alanların alt havza verileri Table 4. Sub-watershed data of reservoir, lake and/or vulnerable wetlands in Marmara Region

\begin{tabular}{|c|c|c|c|c|c|c|c|c|}
\hline Alt havza & $\begin{array}{c}\text { Alan } \\
\left(\mathrm{km}^{2}\right)\end{array}$ & $\begin{array}{c}\text { Ortalama } \\
\text { debi } \\
\left(\mathrm{m}^{3} / \mathrm{s}\right)\end{array}$ & $\begin{array}{l}\text { Yağıș (mm/ } \\
\text { yıl) (IDW } \\
\text { interpola- } \\
\text { ted) }\end{array}$ & $\begin{array}{c}\mathrm{Su} \\
\text { verimi } \\
(\mathrm{mm} / \mathrm{y} 1 \mathrm{l})\end{array}$ & $\begin{array}{c}\text { Ak1ş } \\
\text { katsay1s1 } \\
(\%)\end{array}$ & $\begin{array}{l}\text { En yakın } \\
\text { meteoroloji } \\
\text { istasyonu }\end{array}$ & $\begin{array}{l}\text { Ortalama } \\
\text { yükseklik } \\
\text { (m) }\end{array}$ & $\begin{array}{l}\text { Ortalama } \\
\text { eğim } \\
(\%)\end{array}$ \\
\hline Altınkulaç & 34,75 & 0,292 & 629,49 & 265,00 & 42,10 & Edremit & 274,18 & 24,29 \\
\hline Avcidere & 36,25 & 0,493 & 753,59 & 428,89 & 56,91 & Kocaeli & 553,40 & 41,15 \\
\hline Bayramdere & 69,99 & 0,46 & 621,15 & 207,27 & 33,37 & Çanakkale & 239,66 & 26,92 \\
\hline Çakıldere & 55,04 & 0,346 & 727,47 & 198,25 & 27,25 & Kumköy & 154,44 & 10,53 \\
\hline Çinardere & 58,05 & 0,793 & 627,65 & 430,80 & 68,64 & Çanakkale & 217,86 & 21,41 \\
\hline Değirmendere & 40,88 & 0,293 & 570,60 & 226,03 & 39,61 & Kırklareli & 607,90 & 21,51 \\
\hline Göçbeyli Deresi & 133,37 & 1,56 & 780,95 & 368,87 & 47,23 & Kocaeli & 222,69 & 15,92 \\
\hline Göksu Deresi & 394,03 & 6,01 & 792,45 & 481,01 & 60,70 & Kocaeli & 287,71 & 20,27 \\
\hline Işıklar Deresi & 141,23 & 1,41 & 599,08 & 314,85 & 52,55 & Tekirda $\breve{g}$ & 336,89 & 21,24 \\
\hline Işıklar Deresi & 60,57 & 0,449 & 583,33 & 233,77 & 40,08 & Tekirdağ & 228,80 & 31,81 \\
\hline Istıranca & 291,48 & 2,34 & 674,21 & 253,17 & 37,55 & Kumköy & 207,56 & 14,08 \\
\hline Kabakoz Deresi & 80,21 & 1,35 & 824,25 & 530,78 & 64,39 & Kocaeli & 139,21 & 21,40 \\
\hline Kağıthane & 175,91 & 2,04 & 941,98 & 365,72 & 38,82 & Kumköy & 94,29 & 15,96 \\
\hline Karadere & 252,15 & 2,17 & 733,43 & 271,40 & 37,00 & Kocaeli & 632,64 & 29,61 \\
\hline Karadere & 22,38 & 0,21 & 766,50 & 295,91 & 38,61 & Yalova & 293,16 & 27,93 \\
\hline Karanlık Dere & 78,71 & 0,743 & 641,30 & 297,69 & 46,42 & Edremit & 546,94 & 30,76 \\
\hline Karasu-İnceğiz & 183,8 & 0,959 & 704,46 & 164,54 & 23,36 & Kumköy & 147,95 & 10,78 \\
\hline Kaynarca & 82,01 & 0,466 & 626,88 & 179,19 & 28,58 & Edremit & 196,36 & 20,42 \\
\hline Kilıncı Dere & 62,43 & 0,458 & 869,93 & 231,35 & 26,59 & Kumköy & 92,25 & 13,58 \\
\hline Kirazdere & 254,02 & 5,29 & 731,73 & 656,74 & 49,75 & Kocaeli & 841,72 & 39,32 \\
\hline K.Kumla Dere & 20,69 & 0,3 & 811,53 & 457,26 & 56,35 & Yalova & 452,12 & 34,66 \\
\hline Kocabaş Deresi & 167,02 & 1,31 & 639,11 & 247,35 & 38,70 & Edremit & 493,32 & 28,74 \\
\hline Kocabaş Deresi & 968,92 & 7,71 & 632,24 & 250,94 & 39,69 & Edremit & 306,55 & 22,71 \\
\hline Kocaçay & 48,36 & 0,958 & 647,44 & 624,72 & 56,49 & Edremit & 658,91 & 30,13 \\
\hline Kocaçay & 41,99 & 0,186 & 621,76 & 139,69 & 22,47 & Çanakkale & 392,67 & 28,12 \\
\hline Kocadere & 197,9 & 2,54 & 576,98 & 404,76 & 70,15 & Kırklareli & 521,12 & 26,43 \\
\hline Kocadere & 65,09 & 0,551 & 893,05 & 266,96 & 29,89 & Bursa & 568,89 & 32,08 \\
\hline Kocadere & 75,96 & 0,762 & 831,30 & 316,36 & 38,06 & Yalova & 634,98 & 38,99 \\
\hline Kovandere- & 112,07 & 0,631 & 602,66 & 177,56 & 29,46 & Tekirdağ & 183,37 & 10,46 \\
\hline Kovanlık & 73,5 & 2,423 & 652,13 & 1039,62 & 59,42 & Edremit & 730,82 & 45,60 \\
\hline Kumcağız & 49,65 & 0,703 & 789,78 & 446,52 & 56,54 & Kocaeli & 74,90 & 11,88 \\
\hline Kurudere & 29,25 & 0,781 & 795,96 & 842,04 & 15,79 & Kocaeli & 142,38 & 18,08 \\
\hline Malava Deresi & 112,87 & 2,89 & 828,52 & 807,47 & 57,46 & Kumköy & 115,74 & 16,61 \\
\hline Ozan Deresi & 78,07 & 2,76 & 815,46 & 1114,89 & 36,72 & Kocaeli & 227,36 & 21,57 \\
\hline Pabuçdere & 85,26 & 1,01 & 616,87 & 373,58 & 60,56 & Kırklareli & 431,41 & 27,94 \\
\hline Sarıçay & 212,07 & 0,998 & 615,35 & 148,41 & 24,12 & Çanakkale & 408,20 & 28,64 \\
\hline Sarısu-İzzettin & 79,82 & 1 & 755,76 & 395,09 & 52,28 & Kumköy & 87,79 & 12,52 \\
\hline Sellimandıra & 54,28 & 1,49 & 782,23 & 865,67 & 70,67 & Yalova & 577,63 & 36,99 \\
\hline Suludere & 34,28 & 0,627 & 769,20 & 576,81 & 74,99 & Kocaeli & 550,75 & 41,17 \\
\hline Velikadere & 307,11 & 5,14 & 588,41 & 527,81 & 59,70 & Kirklareli & 532,59 & 24,65 \\
\hline Yağcidere & 17,27 & 0,2 & 770,75 & 365,21 & 47,38 & Yalova & 356,48 & 29,01 \\
\hline Yalakdere & 269,91 & 2,35 & 766,62 & 274,57 & 35,82 & Yalova & 358,15 & 30,86 \\
\hline Yenidüz Deresi & 105,63 & 2,01 & 789,22 & 600,09 & 76,04 & Kocaeli & 149,59 & 14,30 \\
\hline Yamandere & 31,04 & 0,346 & 808,10 & 351,53 & 43,50 & Bursa & 523,76 & 19,92 \\
\hline Yeşildere & 58,43 & 1,32 & 830,18 & 712,43 & 45,82 & Kocaeli & 128,27 & 19,53 \\
\hline Y1lgindere & 17,69 & 0,22 & 788,18 & 392,19 & 49,76 & Kocaeli & 145,74 & 21,37 \\
\hline Yulaflı Dere & 207,05 & 2,27 & 778,49 & 345,75 & 44,41 & Kocaeli & 136,64 & 15,24 \\
\hline Gönen Çayı & 643,64 & 7,36 & 643,56 & 360,61 & 56,03 & Edremit & 505,44 & 28,96 \\
\hline
\end{tabular}


$\mathrm{mm}$ aralığında seyretmesi beklenir. Yıllık bazda ve mevsimsel değişkenlikler de dikkate alınmalıdır.

Öte yandan akarsu etütleri; su kalitesi parametreleri ve akarsu koridorlarının orta ve orta-iyi seviyede olduğunu ortaya koymuştur. Bir başka deyişle yerleşimlerin dışında kalan akarsular ve dere kıyısı ekosistemleri orta-iyi seviyede sağlıklı ve fonksiyoneldirler. Yerleşimlerin yakınlarında ise su kalitesi parametrelerinde bozulmalar ve akarsu kıyı ekosistemlerinde tahribatlar yaygın olarak görülmektedir. Dere kıyılarında rekreasyon faaliyetleri ölü örtü oluşumunu önlemekte ve topraklarda sıkışmaya yol açmaktadır. Akarsu koridorlarının restorasyonunda insan faaliyetleri, özellikle rekreasyonla ilgili taşıma kapasitesi dikkate alınmalıdır zira toprak sıkışması dere kıyı zonunun fonksiyonlarını yerine getirmesi yönünde önemli bir engel, hatta tehdittir.
Arazi etütleri ve meta analiz neticesinde planlamaya kılavuzluk edecek bazı kriter ve göstergeler geliştirilerek aşağıda sıralanmıştır. Su kalitesi, ormancılık veya diğer arazi kullanımlarının etkilerini ortaya koyan önemli bir kontrol mekanizmasıdır. Bir uygulama veya arazi kullanım şeklinin etki seviyesini değerlendirmek bakımından kullanılabilir. Planlama ünitesinin yakınında yer alan su ortamlarında kalite yönünden bir sorun mevcutsa bu durum bazı uygulama hatalarının söz konusu olabileceğinin göstergesi olabilir. Dolayısıyla Hidrolojik Değerlendirme Raporunda ve Dere Kiyıs1 Ekosistemi Yönetim Raporunda öncelikle bu durum ortaya konulmalı, su kalitesi düşük olan dereler belirlenip izlenmelidir.

Araştırma kapsamında gerçekleştirilen arazi etütlerinde aşağıdaki ortalama değerler belirlenmiş ve ulusal/uluslararası standartlarla karşılaştırılmıştır (Tablo 5).

Tablo 5. Arazi ölçümlerinde elde edilen sonuçların ortalaması ve bazı ulusal/uluslararası standartlarla karşılaştırması sonucu uygulama kullanılabilecek kritik değerler

Table 5. Critical values derived from field measurements and comparison with national/international standards that can be used in practice

\begin{tabular}{llccccc}
\hline & & \multicolumn{4}{c}{ Önerilen parametreler } \\
\cline { 3 - 6 } & & 1 & 2 & 3 & 4 & 5 \\
\cline { 3 - 6 } & Ëं $(\mu \mathrm{S} / \mathrm{cm})$ & $\mathrm{pH}$ & $\begin{array}{c}\text { Bulanılık } \\
\text { NTU }\end{array}$ & $\begin{array}{c}\text { Oksijen } \\
\mathrm{mg} / \mathrm{l}\end{array}$ & $\begin{array}{c}\text { Süspanse sediment } \\
(\mathrm{g} / \mathrm{l})\end{array}$ \\
\hline Su kalitesi & Ölçüm & $<750$ & $6-8$ & $<30$ & $<5$ & $<0,7$ \\
& SKKY $^{1}$ & & $6,5-8,5$ & & $<8$ & $<0,5$ \\
& EPA $^{2}$ & $<1275$ & & $<29$ & & $<0,5$ \\
\hline \multirow{2}{*}{ Önerilen } & & $<500$ & $6-8$ & $<30$ & $<8$ & \\
\hline
\end{tabular}

${ }^{1}$ Su Kirliliği Kontrol Yönetmeliği birinci sınıf yüzeysel su kalitesi kriterleri (SKKY, 2004)

${ }^{2}$ ABD Çevre Koruma Ajansı birinci sınıf yüzeysel su kalitesi kriterleri (EPA, 2018)

Önerilen değerlerin dişında kalan ölçüm değerleri dere su kalitesinin bozuk olabileceği sonucuna götürecektir. Yine de ölçümlerin tekrar edilmesi ve zamansal düzlemde izlenmesi gerekmekte, kötüye gidiş durumunda olası nedenleri ile birlikte kayıt altına alınmalıdır. Parametreleri kısaca açıklamak gerekirse;

Elektriksel iletkenlik sudaki tuzluluğu ifade eden bir parametre olup ölçülen derelerde $750 \mu \mathrm{S} / \mathrm{cm}^{\prime}$ ye kadar değerler elde edilmiş olsa da kirlenmiş derelerde genellikle $500 \mu \mathrm{S} / \mathrm{cm}$ altı değerlere rastlanmıştır. Dolayısıyla kriter önerisi olarak bu değeri almak daha emniyetli olacaktır. Sudaki hidrojen aktivitesi için $\mathrm{pH}$ için 6-8 aralığı genellikle tüm yönetmelik ve standartlarda yaygındır. Yine arazi çalışmalarında $8 \mathrm{mg} / 1$ altında oksijen konsantrasyonu değerlerine rastlanmış olsa da ulusal ve uluslararası standartlar genellikle bu değeri sınır değer olarak kabul etmektedir. Sicak dönemlerde ve akışın düşük olduğu zamanlarda bu değerin altına kirli olmayan derelerde de inilebilmekte, fakat normal akış koşullarında oksijen konsantrasyonunun $8 \mathrm{mg} / \mathrm{l}$ üzerinde olması sucul ortamın habitat kalitesi bakımından önemlidir. Sularda bulanıklığa neden olan faktörler; süspanse sedimentler, mikroorganizmalar, kimsasal ve organik maddelerdir ve kirliliğin önemli bir göstergesidir. Kristal berraklığında sularda bulanıklık değeri 1 NTU'nun altındadır. Bulanıklık değeri 5 NTU ve üzerinde suyun şeffaflığı iyice azalmaktadır. Genellikle berrak akan dere sularının bile zaman zaman birtakım akış değişkenliği ve mevsimsel etkilerle bulanıklığ1 artabilir. Bu nedenle sınır bulanıklık değeri 30 NTU olarak önerilmektedir. Süspanse sediment konsantrasyonu yağış sonrası veya kurak dönemlerde değil normal akış koşullarında ölçülmelidir aksi halde çok farklı değerler ölçülebilir.

Öte yandan proje kapsamında yürütülen arazi ça- 
lışmaları sonuçlarına göre sağlıklı bir dere kıyısı ekosisteminin hidroekolojik bakımdan bazı temel özelliklerinin olması gerektiği belirlenmiştir. $\mathrm{Bu}$ özellikler sınıflandırılmış ve en düşük seviyede olması gerekenler aşağıda sıralanmıştır (Tablo 6). Dere ve dere kıyısı ekosistemini koruyan tampon zon genişliği ile ilgili altı sınır değer $10 \mathrm{~m}$ olarak önerilmekle beraber bu genişliğin dere kıyısı ekosisteminin sıklığ1, tipi (odunsu/otsu vb.), dere ve şev eğimi, dere genişliği, ekolojik zon, havzadaki konum ve dere tipine bağlı olarak uzmanlarca belirlenmesi gerektiği düşünülmektedir. Genel bir yaklaşım olarak eğimin yüksek olduğu ağaç kesimleri olan yukarı havzalarda - ki bu havza zonunda a ve b tipi dereler görülmektedir - eğimin etkisini azaltmak ve erozyonu minimize etmek için, öte yandan akarsuyun taşkın ovasında yer alan ağaç kesimleri için yine tampon zon geniş tutulmalıdır. Buna karşın dere genişliği veya eğim tek başına kriter olarak alınmamalıdır.

Odunsu moloz, akarsu kiyı zonunda yer alan odunsu bitkilerin dal, gövde ve köklerinden oluşan birikintilerdir. Odunsu moloz birikintileri ve ölü odun akarsu koridoru habitatını paylaşan sucul ve karasal canlıların yaşamında son derece önemli işlevlere sahiptir. Habitat özelliklerini etkileyen diğer önemli parametre de akarsu kıyı ekosisteminin gölgeleme etkisidir. Gölgeleme etkisi suyun aşırı 1sınmasını önleyen bir mekanizma olup daha çok boylu bitkilerce sağlanmaktadır.

Tablo 6. Arazi ölçümlerinde elde edilen sonuçlara göre hidroekolojik yönden sağlıklı ve fonksiyonel bir dere kıyısı ekosisteminin asgari kriterleri

Table 6 . The minimum criterion of healthy and functional riparian ecosystems based on field measurements

\begin{tabular}{|c|c|}
\hline $\begin{array}{l}\text { Hidroekolojik } \\
\text { parametreler }\end{array}$ & Kriter \\
\hline \multirow{3}{*}{$\begin{array}{l}\text { Odunsu moloz } \\
\text { ve ölü odun }\end{array}$} & $\begin{array}{l}\text { Dere gözlem noktasının } 100 \mathrm{~m} \text { lik segmentinde ( } 50 \text { metre alt, } 50 \text { metre üst) dere yatağında en } \\
\text { az } 1 \text { odunsu moloz birikintisi }\end{array}$ \\
\hline & $\begin{array}{l}\text { Dere gözlem noktasının } 100 \mathrm{~m} \text { lik segmentinde ( } 50 \text { metre alt, } 50 \text { metre üst) dere şevlerinin } \\
\text { herhangi birinde en az } 1 \text { odunsu moloz birikintisi }\end{array}$ \\
\hline & $\begin{array}{l}\text { Dere gözlem noktasının } 100 \mathrm{~m} \text { lik segmentinde ( } 50 \text { metre alt, } 50 \text { metre üst) dere şevlerinin } \\
\text { herhangi birinde en az } 2 \text { adet dikili veya yatık ölü odun (min } 8 \mathrm{~cm} \text { çap). }\end{array}$ \\
\hline Gölgeleme & Dere su yüzeyinin en az \%20 sinin gölgeleniyor olmas1 \\
\hline $\begin{array}{l}\text { Tampon zon } \\
\text { genişliği }\end{array}$ & $\begin{array}{l}\text { Dere kıyısı ekosisteminin sıklığı, tipi (odunsu/otsu vb.), dere ve şev eğimi, dere genişliği, eko- } \\
\text { lojik zon, havzadaki konum ve dere tipine bağlı olarak her bir şevde minimum } 10 \text { metre olacak } \\
\text { şekilde uzmanlarca belirlenen minimum geniş̧lik }\end{array}$ \\
\hline
\end{tabular}

Planlama ünitesi yakınında yer alan akarsuların sel (aşırı yağışlar sonucu eğimin yüksek olduğu akarsuların yukarı kesimlerinde gerçekleşen ve suyla birlikte ağaç gözdeleri, moloz, kaya vb. malzemenin çok hızlı biçimde aşağı yönlü hareketi) ve taşkın (aşırı yağışlar sonucu eğimin genellikle düşük oldu- ğu aşağı akarsu kesimlerinde akışın dere yatağının dışına taşması ile gerçekleşen hidrolojik olay) riski altında olup olmadığını belirlemenin en kesin yöntemi arazi gözlemleridir. Bir akarsu kesitinde bu iki oluşumun şiddeti ve frekansını tahmin etmeye yönelik indikatörler bulunmaktadır (Tablo 7).

Tablo 7. Bir akarsu kesitinde sel-taşkın riskini ortaya koyabilecek bazı temel indikatörler Table 7. Some basic indicators of a stream cross section for torrent-flood risk

\begin{tabular}{lll}
\hline $\begin{array}{l}\text { Sel-taşkın } \\
\text { indikatörleri }\end{array}$ & Orta seviye risk & Yüksek seviye risk \\
\hline $\begin{array}{l}\text { Sediment } \\
\text { boyutu }\end{array}$ & $\begin{array}{l}\text { Çapı } 10 \mathrm{~cm} \text { altı taş ve çakı1 } \\
\text { karışımı sediment }\end{array}$ & $\begin{array}{l}\text { Çap1 } 10 \mathrm{~cm} \text { üstü taş ve kayaların dere yatağında varlığı. } \\
\text { İi taş ve kayaları dere yatağında fazla gömülmeden } \\
\text { durması sık bir sel varlığının göstergesidir }\end{array}$ \\
\hline Taşkın genişliği & Taşkın alan genişliği $30 \mathrm{~m}$ ve altı & Taşkın alanı genişliği 30 m üzeri \\
\hline Sel kalıntıları & $\begin{array}{l}\text { Yer yer küçük ve orta çaplı ağaç } \\
\text { kök ve gövdelerinin dere şevle- } \\
\text { rinde ve dere yatağında varlığ1 }\end{array}$ & $\begin{array}{l}\text { Orta ve büyük çaplı ağaç kök ve gövdelerinin dere şev- } \\
\text { lerinde ve dere yatağında varlı̆̆ı. Zarar görmüş köprü ve } \\
\text { benzeri hidrolik yaplar }\end{array}$ \\
\hline Kanal erozyonu & $\begin{array}{l}\text { Stabilitesini ve vejetasyon yapısı- } \\
\text { nı yitirmiş kanal yapısı }\end{array}$ & $\begin{array}{l}\text { Stabilitesini ve vejetasyon yapısını yitirmiş kanal yapısı. } \\
\text { Kanal şevlerinde göçmeler ve oyulmalar yaygın }\end{array}$ \\
\hline
\end{tabular}


Burada dikkat edilmesi gereken husus sel-taşkının boyutu ve frekansıdır, zira insan etkisi olmayan (yerleşim, kanallaştırma vb.) tamamen ormanlık havzalarda da belli periyotlarda sel-taşkın olaylar1nın gerçekleşmesi beklenir. Önemli olan bu doğal olguların can ve mal kaybına yol açıp açmayacağıdır. Tablo 7' de verilen indikatörler yardımıyla taşkın riskinin orta seviye veya yüksek riskli olduğu belirlenirse akarsu çevresinde yer alan yerleşimlerle ilgili önlemler alınmalı, hidrolik yapıların bakımına özen gösterilmelidir. Can ve mal kaybına yol açabilecek düzeyde şiddetli - düşük frekanslı - sel-taşkın olayları orman yönetim uygulamaları ile belli oranda azaltılabilir, fakat önlenemez. Tepe çatısı kapalılığının ve ölü örtünün korunması yanında, özellikle orman yolları üzerinde oyuntu oluşumlarının önlenmesi sel-taşkın riskini azaltmada etkili olabilir.

Planlamada toprak koruma amaçlı olarak "iyi uygulama rehberi" geliştirilmesi ve tüm ormancılık faaliyetlerinde kullanılması gerekmektedir. Zira eğimin olduğu her noktada erozyon riski söz konusu olabilir. Toprak koruma ormancılıkta iki temel açıdan ele alınmalıdır; erozyon ve kütlesel hareketler. Orman- cılıkta en çok rastlanan erozyon şekilleri su ve rüzgar erozyonlarıdır. Rüzgar erozyonuna karşı önlemler (rüzgar perdeleri, şeritleri, kumul ıslah önlemleri vb.) oldukça net olmakla beraber su erozyonuna karş1 o kadar açık olduğu söylenemez. Kütlesel hareketler ise yine çok farklı şekillerde ortaya çıkabilir. Heyelanda hareket yamacın nem içeriği ile yakından ilişkili iken moloz akıntısında yüzeysel akış önemli rol oynamaktadır (Balc1, 1996).

Genellikle hem erozyonun hem de kütlesel hareketlerin arazide belirtileri gözlenebilmektedir. Su erozyonunda en etkili ekosistem bileşeni tartışması ölü örtüdür. Ölü örtü seviyesi toprağ1 yeterince kaplıyor ve yağmur damlası dispersleştirme etkisini ve yüzeysel akışı önleyebiliyorsa erozyon anlamında önemli bir sorun ortaya çıkması pek olası değildir. Planlama ünitesindeki meşcerelerde ölü örtü iyi seviyede ve eğim \%50'nin altındaysa genellikle "iyi uygulama rehberi" 1şığında ormancılık faaliyetlerinin yürütülmesi yeterli olacaktır. Eğimin \%50 üzerine çıkması yüzeysel akış oluşumunu teşvik edici olacağından normalin üzerinde bir kapalılığın oluşturulması ve korunmasında yarar vardir (Tablo 8).

Tablo 8. Toprak koruma risk sinıflarını tanımlayıcı kriterler

Table 8. Descriptive criteria for soil conservation risk classes

\begin{tabular}{|c|c|c|c|c|}
\hline Kriter & $\begin{array}{l}\text { Toprak koruma risk } \\
\text { Sinıfi }\end{array}$ & $\begin{array}{c}\text { Risk yok } \\
\text { tüm kriterler mevcut }\end{array}$ & $\begin{array}{l}\text { Riskli } \\
\begin{array}{l}\text { Kriterlerden en az biri } \\
\text { eksik }\end{array}\end{array}$ & $\begin{array}{c}\text { Çok riskli } \\
\text { kriterlerden birden faz- } \\
\text { lası eksik }\end{array}$ \\
\hline & Eğim & $<\% 50$ & $\% 50-100$ & $>\% 100$ \\
\hline 1 & Ölü örtü kalınlığg1 & \multicolumn{3}{|c|}{ En az $5 \mathrm{~cm}$ ölü örtü mevcut } \\
\hline 2 & Tabaka erozyonu & \multicolumn{3}{|c|}{ Tabaka erozyonu düşük seviyede } \\
\hline 3 & Oyuntu oluşumu & \multicolumn{3}{|c|}{ Oyuntu oluşumu yok } \\
\hline 4 & Kütlesel toprak hareketi & \multicolumn{3}{|c|}{ Heyelan veya benzeri kütlesel hareket beklenmiyor } \\
\hline \multicolumn{5}{|c|}{ Uygulanacak müdahale } \\
\hline & Meşcere göğüs yüzeyi & - & $+\% 10$ & $+\% 20$ \\
\hline & & $\begin{array}{l}\text { Ormancilık uygulama- } \\
\text { larında standart toprak } \\
\text { koruma önlemleri }\end{array}$ & $\begin{array}{l}\text { Eksik olan kriteri ta- } \\
\text { mamlayıc1/iyileştirici } \\
\text { uygulama yapılmalıdır. } \\
\text { Eğimin yüksek olması } \\
\text { dışında eksik bir kriter } \\
\text { olmaması durumunda } \\
\text { eğimin getireceği risk } \\
\text { nedeniyle göğüs yü- } \\
\text { zeyini normalin \%10 } \\
\text { fazlasında bırakmak } \\
\text { yararlı olacaktır. }\end{array}$ & $\begin{array}{c}\text { Eksik olan kriterleri } \\
\text { tamamlayıc1/iyileştirici } \\
\text { uygulama yapılmalıdır. } \\
\text { Eğimin yüksek olması } \\
\text { dışında eksik bir kriter } \\
\text { olmaması durumunda } \\
\text { eğimin getireceği risk } \\
\text { nedeniyle göğüs yüzeyi- } \\
\text { ni normalin \%20 fazla- } \\
\text { sinda bırakmak yararlı } \\
\text { olacaktır. }\end{array}$ \\
\hline
\end{tabular}

Marmara Bölgesi içerisinde veya yakınında yer alan Susurluk, Ergene ve Sakarya gibi akarsuların temel sorunu kirliliktir. Kirlilik nedenleri arasında noktasal kaynaklar (fabrika, kanalizasyon vb.) ön sirada yer alsa da, yer yer noktasal olmayan kay- naklar (tarım, orman, mera vb.) da ağırlık kazanmaktadır. Akarsulardan sürekli sulama suyu çekiyor olması da dikkate alındığında bu büyük akarsu havzalarında ormanların yönetilme şeklinin fazlaca bir önemi kalmamaktadır. Dolayısıyla kritik ve 
hassas su ortamlarına odaklanılması fayda maliyet yönünden daha etkin olacaktır.

Öte yandan arazi kullanma durumu, kirlilik kaynakları ve sulama suyu çekilmesi gibi yaygın faaliyetler orman planlamanın havza planlama ile entegre edilmesinin önemini ortaya koymaktadır. Orman planlamacı hangi havzada çalıştığını ve havzanın özelliklerini iyi bilmelidir. Dolayısıyla su üretimi bakımından doğru bir orman yönetimi için planlama öncesi;

- Havza hidrolojik sisteminin ve

- Akarsu koridorlarının

Etüt edilmesi gerektiği ortadadır.

Orman planlamada kritik ve hassas su ortamlarına ağırlık verilmesi gerektiği yukarıda ifade edilmişti. Bu kapsamda nasıl bir planlama yaklaşımının benimsenmesi gerektiği konusunu irdelemek gerekirse öncelikle nasıl bir su ortamından söz edildiği bilinmelidir. Hassas ve kritik su ortamlarından kastedilen ekolojik olarak hassas göl, lagün veya haliç gibi su ortamları, kritik su ortamından kastedilen ise su üretim ve kullanımı yönünden önemli baraj ve bent gibi yapılardır.

Öte yandan LAI ölçümleri, ölü örtü ve diri örtü sonuçları analiz edildiğinde sadece LAI ölçümleri ile ölü örtü miktarı arasında anlamlı pozitif bir ilişki bulunduğu ortaya çıkmıştır. Yaprak yüzey indeksi arttıkça ölü örtü miktarında artış görülmektedir. Yaprak yüzeyinin artışı ile daha fazla biyokütlenin ve bunun sonucu ölü örtü birikiminin olması, 1ş1k ve sıcaklık koşullarının nispeten düşük oluşuyla da ayrışmanın yavaş gerçekleşmesi beklenen bir durum olmakla beraber, LAI ölçümlerinin ölü örtü kalınlığ ${ }_{1}$ ile ilişkilendirilebilmesi önemlidir. Zira mevcut subjektif kapalılık değerlendirmeleri ölü örtü seviyesi ile ilgili bir veri sağlamamakta, fakat LAI ölçümleri bunu sağlamaktadır. Dolayısıyla sağladığı veriler dikkate alındığında ve NDVI ile ilişkilendirilebiliyor olması LAI ölçümlerinin yaygınlaştırılması gerektiğini ortaya koymaktadır. Öte yandan LAI ölçümleri ile diri örtü yoğunluğu arasında anlamlı bir korelasyon bulunamamıştır.

Yağışın en fazla düştüğü dönem yani kış aylarında LAI ölçüm değeri, geniş yapraklı ormanlarda iğne yapraklı ormanlardan daha düşüktür. $\mathrm{Bu}$ durum intersepsiyonu düşük tutmak için baraj havzalarında kışın yaprağını döken türlerin kullanılması gerektiği yaklaşımını desteklemektedir. Öte yandan ülkemizde en yağışlı mevsim kış olmakla beraber ilkbahar ve sonbahar aylarında da yüksek seviyede yağış gerçekleştiği bilinmektedir. Bu dönemlerde iğne yapraklı ve geniş yapraklı meşcereler arasında ciddi bir intersepsiyon farkının olmayabileceğini, hatta yapraklı meşcerelerde daha fazla olabileceğini ortaya koymaktadır. Dolayısıyla su üretim havzalarında sadece yapraklı-iğne yapraklı ayrımına değil, intersepsiyonu etkileyecek tüm meşcere parametrelerine (tabakalılık, LAI ölçümleri, tür karışımı, silvikültürel işlemler vb.) bakmakta yarar vardır. Baraj havalarında geniş yapraklı türler kullanılması gerektiği doğru, fakat yetersiz bir yaklaşımdir.

NDVI ve LAI ölçümleri arasında doğrusal bir ilişki saptanmıştır. Fakat bu güçlü bir korelasyonu ifade etmemiştir. İlişkinin güçlü olmaması iki nedene dayalı olabilir. Birincisi meşcere türlerinin değişkenliğidir. Eğer saf ve tek tabakalı bir orman yapıs1 söz konusu olsaydı ilişki daha net görülebilirdi. Diğeri ise ölçüm yönüdür. LAI ölçümleri tepe çatısını alttan görmekte, NDVI ise uydu görüntüsünden elde edildiği için üstten görmektedir. Kısaca özetlemek gerekirse, Marmara Bölgesi’ndeki gibi değişken meşcere yapılarında bile anlamlı bir korelasyon bulunduğuna göre saf orman yapılarının yer aldığ 1 geniş alanlarda LAI ölçümlerini NDVI ile ilişkilendirmek mümkün olabilir.

\section{Genel Değerlendirme ve Öneriler}

Meta analiz bulguları genel anlamda ağaç kesim yoluyla su verimini artırmaya yönelik uygulamaların ülkemiz koşullarında etkili olamayacağını ortaya koymaktadır. Ağaç kesim yoluyla su verimi artışı hem ekonomik fayda sağlayacak seviyeye ulaşmamakta, hem de kısa süreli olmaktadır. Dahası gerekli önlemler alınmadan gerçekleştirilecek ağaç kesimi ve taşıma çalışmaları su kalitesini bozabilmektedir. Öte yandan ülkemizde yaz aylarında barajlardan buharlaşma o kadar yüksek seviyeye çıkmaktadır ki üretilecek fazladan su barajlardan buharlaşma yoluyla atmosfere geri dönebilmektedir. Sel ve taşkın riskinin ülke genelinde yaygın olması da özellikle eğimli arazilerde şiddetli aralamaların risk yaratabileceği anlamına gelmektedir. Dolayısıyla etkin bir su kaynakları yönetimi ile zaten çok daha yüksek seviyede su kazancı elde edilebilir.

Su verimini artırmaya çalışmak yerine su rejimi ve kalitesine ağırlık vermek hidroekolojik bakımdan çok daha doğru bir yaklaşım olacaktır. Su rejiminin düzenlenmesi, yani akışın mevsimlere yayılması yüzeysel akışın mümkün olduğunca azaltılması ile gerçekleştirilebilir. Bunun için önerilen planlama ilkeleri şunlardır;

- Orman yönetim ve planlaması odun hammaddesi üretimi ve orman çerçevesinden "orman ve ilişkili ekosistemlerin ve sundukları hizmetlerin üst 
düzey ve sürdürülebilir yönetimi ve planlaması" çerçevesine genişletilmesi gerekmektedir. Zira hem orman içinde, hem de yakınında mera, sulak alan, yerleşim ve tarım alanları yer almaktadır. Planlama sürecinde tüm komşu ve ilişkili arazi kullanımları dikkate alınmalıdır. Yetkili ve sorumlu birimlerin de sürece dahil olması sağlanmalıdır.

- Baraj ve benzeri rezervuarların planlanması ve yönetimi diğer kamu kuruluşlarınca gerçekleştiriliyor olsa da yukarı havzada yer alan su ortamları (akarsu, göl, vb.) ormanlarla ekolojik olarak sıkı bir etkileşim içerisindedir. Orman planlamada ekolojik olarak ilişkili su ortamlarının durumu ve değişimi hem su, hem de habitat kalitesi yönünden izlenmelidir.

- Ölü örtüye zarar vermek suretiyle su kalitesini bozucu ve erozyon yaratma potansiyeline sahip ormancılık uygulamaları ile ilgili bazı yeni teknik ve yaklaşımlar geliştirilebilir. Bu yaklaşımlar öncelikle doğal sulak alan ve baraj havzalarında uygulanmalı ve yaygınlaştırılmalıdır.

- Ormancılık uygulamalarının zamanlaması hava ve iklim koşullarına göre planlanarak ekosisteme verilebilecek zararlar (iyi uygulama rehberi ile) en aza indirilebilir. Erozyon ve su kalitesindeki bozulmalar sadece insan etkisiyle gerçekleşmektedir. Dolayısıyla bu konuda önlemler uygulama ile ilişkili olarak ele alınmalıdır. Bu tespitten yola çıkılarak "su ve toprak korumaya" yönelik "İyi Uygulama Rehberi” hazırlanmalı ve tüm ormancilık uygulama dokümanlarına ve kapasite geliştirme süreçlerine dahil edilmelidir.

- Akarsu kıyısı ekosistemlerinin önemi anlaşılmal1 ve bu alanlardaki özel ormancılık teknikleri benimsenmelidir.

- İyi Uygulama Rehberi sadece sulak alan veya baraj havzalarında değil, tüm ormanlarda uygulanmalidir.

Her planlama ünitesi kendine özgü hidroekolojik ve sosyal yapıya sahiptir. Dolayısıyla planlama öncesi havza sisteminin detaylı biçimde analiz edilmesi gerekmektedir. Bu da uzman hidrolojist ve havza planlama uzmanlarınca hazırlanacak havza Hidrolojik Değerlendirme Raporu (HDR) ile gerçekleştirilebilir. İdeal olarak bu değerlendirmelerin ekolojik değerlendirme yapma kapasitesine sahip uzmanlarca gerçekleştirilmesi yerinde olacaktır. Burada ilgili kamu kurumları arasında iş birliği yapılması da söz konusu olabilir. Fakat su üretiminin yukarı havzalarla ilgili bölümünün ormancılık sektörüne entegre olması isteniyorsa hidroekolojik değerlendirmelerin de ormancılık sektörü içerisinde çözümlenmesi yerinde olacaktır. Bu konuda yeterli bilgi ve teknoloji Orman Fakültelerinde mevcuttur.
Ülkemizin tüm ormanları ve havzaları için standart bir planlama reçetesi vermek olası değildir. İklim değişikliği gibi antropojenik risklerin (kentleşme, hava kirliliği, madencilik vb.) etkileri önceden belirlenmeli ve buna yönelik planlama önlemleri alınmalıdır. Buna proaktif ormancılık yaklaşımı adı verilmektedir. $\mathrm{Bu}$ yaklaşıma göre riskler ve iklim ve sosyo-ekonomik koşullardaki değişimler önceden belirlenmekte ve buna göre çözümler üretilmektedir. Örneğin; artan sicaklık ve azalan yağış koşullarının yangın riskini artırması beklenmekteyse uygun yönetim yaklaşımları ile yangın riskini azaltıcı planlama prensipleri uygulamaya konulabilir.

$\mathrm{Bu}$ çalışma, orman ve su ilişkisi açısından orman yönetiminde Orman Genel Müdürlüğü (OGM) için önemli bir kaynaktır. Havza ölçeğinde tüm arazi kullanımları ve arazi örtüleri ele alınarak hidrolojik sistem değerlendirildiğinden hassas alanlar, sulak alanlar, biyolojik çeşitlilik ve habitatları korumayı da dikkate almaktadır. Bu bakımdan bu çalışma Doğa Koruma ve Milli Parklar Genel Müdürlüğü için de önem taşımaktadır.

Akarsu kıyı ekosistemleri su ortamları için doğal bir düzenleme mekanizması olduğu için planlamada bu ekosistemlere ağırlık vermek gerekmektedir. Bunun için ayrıca Dere Kıyısı Ekosistemleri Yönetim Planları (DKYP) hazırlanmalıdır. Bu planlarda mevcut akarsu koridorlarının fonksiyonellik ve sağlık durumları ortaya konulmalı, geliştirme yöntem ve uygulamaları belirlenmeli ve gelişmeleri (iyiye veya kötüye gidiş) zamansal olarak izlenmelidir.

HDR'de planlama biriminin yer aldığı ana havza ve özellikleri, içinde ve çevresinde yer alan doğal ve yapay su ortamları, kritik akarsu koridorları ve klimatik/hidrolojik riskler belirlenmelidir. Hem havza hem de dere kıyısı planlarında bir izleme mekanizması da yer almalıdır. Belirlenen kritik akarsu kesitleri belirli periyotlarda izlenmeli ve raporlanmalıdır. Böylece planlamaya konu olan ünitede yer alan hassas ekolojik zonlar her planlama döneminde değerlendirilmeli ve kötüye gitme ya da doğallıktan uzaklaşma durumunda önlem alınmalıdir.

Kisaca özetlenecek olursa;

- Orman Amenajman Tebliğinde su ve toprak koruma fonksiyonları üst ölçeğe çıkarılmalı ve tüm ormancılık uygulamalarına dahil edilmelidir.

Zira eğimin ve insan etkisinin olduğu her durumda bir su erozyonundan ve/veya kütlesel toprak hareketinden söz edilebilir. Dolayısıyla tüm ormancılık faaliyetlerini kapsayacak şekilde Su 
ve Toprak Korumaya Yönelik Iyi Uygulama Rehberi hazırlanmalıdır. Bu rehberin eğitimi başta Orman İdaresi ve Planlama Dairesi personeli olmak üzere tüm Orman Teşkilatında yaygınlaştırilmalidir.

- Orman Amenajman planlar hazırlı̆̆ öncesi plan ünitesinin yer aldığ havza ile ilgili HDR ve DKYP planlart hazırlanmalıdır. Böylece amenajman planları bulunduğu havza sistemi ile uyumlu şekilde planlanabilir. Planlama ünitesi içinde veya yakınında yer alan su ortamlarının sürdürülebilir yönetimi ve gelişimi adı geçen planlarda yer alan izleme mekanizması sayesinde garanti altına alınmış olacaktır. Ayrıca bu sayede "orman planlama ve yönetimi", "havza planlama" ve dolayısıyla "Nehir Havzası Yönetim Planları (NHYP)" ile uyumlu hale getirilebilecektir. NHYP'de de ana amaç su ortamlarını daha iyi seviyeye çıkarmak olduğundan orman planlama ile doğal bir uyum ve eşgüdüm sağlanmış olacaktır.

Bu konuda çalışmalara pilot bir uygulama çalışması kapsamında başlanmasında yarar vardır. Zira iklim değişikliğinin etkileri beklenenden daha hızlı şekilde ortaya çıkmaktadır.

\section{Teşekkürler}

Bu çalışmada OGM 10.6601/2013 nolu “Ormanların Su ve Toprak Koruma Fonksiyonlarının Planlamaya Yönelik Değerlendirmesi: Marmara Bölgesi Örnek Çalışması” isimli proje bulguları değerlendirilmiştir.

\section{Kaynaklar}

Balcı, N., 1996. Toprak korumas1, İ.Ü. Yayın No: 3947, İstanbul, $490 \mathrm{~s}$.

Biggs, R., Schlüter, M., Biggs, D., Bohensky, E.L., BurnSilver, S., Cundill, G., Dakos, V., Daw, T.M., Evans, L.S., Kotschy, K., Leitch, A.M., Meek, C., Quinlan, A., RaudseppHearne, C., Robards, M.D., Schoon, M.L., Schultz, L., West, P.C., 2012. Toward principles for enhancing the resilience of ecosystem services. Annual Review of Environmental Resources, 37: 421-448.

Bouyoucos, G.J. 1936. Directions for making mechanical analysis of soils by the hydrometer method. Soil Science, 4: 225 - 228 .

DSİ, 2012. 2007 Akım gözlem yıllığı cilt-1 ve cilt-2. T.C. Orman ve Su İșleri Bakanlığ Devlet Su İşleri Genel Müdürlüğü. DSİ Teknoloji Dairesi Başkanlığı Basım ve Foto-Film Şube Müdürlüğü, Ankara.

EPA, 2018. Surface water quality standards. U.S. Environmental Protection Agency. Chapter 62-302. https://www.epa.gov/sites/production/files/2014-12/documents/fl_section62-302.pdf (Ziyaret tarihi: 25.02.2020).
Gökbulak, F., Sengonul, K., Serengil, Y., Yurtseven, İ., Uygur, B., Ozcelik, M.S., 2016. Effect of forest thinning on water yield in a sub-humid Mediterranean oak-beech Mixed forested watershed. Water Resources Management. Pp. 1-11.

IPCC, 2014: Climate Change 2014: Synthesis Report. Contribution of Working Groups I, II and III to the Fifth Assessment Report of the Intergovernmental Panel on Climate Change [Core Writing Team, R.K. Pachauri and L.A. Meyer (eds.)]. IPCC, Geneva, Switzerland, 151 pp.

Middleton, H.R.1930. Properties which influence soil erosion. Tech. Bull. No. 178, USDA.

Özhan, S. 1982. Belgrad ormanındaki bazı meşcerelerde evapotranspirasyonun deneysel olarak saptanmas1 ve sonuçların ampirik modellerle karşılaştırılması. İ.Ü. Orman Fak. Yayınları, İ.Ü. Yayın No: 2906, O.F. Yayın No. 311, İstanbul.

Özhan, S., 2004. Havza amenajmanı. İ.Ü. Orman Fakültesi Havza Amenajmanı Anabilim Dalı, İ.Ü. Rektörlük Yayın No: 4510, Orman Fakültesi Yayın No: 481, İstanbul, 384s.

Pamukçu, P., Erdem, N., Serengil, Y., Randhir, T.O., 2016. Ecohydrologic modelling of water resources and land use for watershed conservation. Ecological Informatics, 36: 31-41.

Pamukçu, P., Serengil, Y., Yurtseven, I., 2014. Role of forest cover, land use change and climate change on water resources in Marmara Basin of Turkey. iForest-Biogeosciences and Forestry, 8: 480-486.

Rammer, W., Seidl, R., 2015. Coupling human and natural systems: Simulating adaptive management agents in dynamically changing forest landscapes. Global Environmental Change, 35: 475-485.

Serengil, Y., 2013. Farklı ormancılık faaliyetlerinin ve orman normlarının su üretimine olan etkisinin hesaplama yöntemlerinin belirlenmesi. Rapor. 54 sayfa.

Serengil, Y., Gökbulak, F., Özhan, S., Hızal, A., Şengönül, K., Balc1, N. ve Özyuvac1, N., 2007. Hydrological impacts of a slight thinning treatment in a deciduous forest ecosystem in Turkey. Journal of Hydrology, 333: 569-577.

Serengil, Y., Özdemir, E., Pamukçu Albers, P., Özkan, U., 2018. İklim değişikliği ile mücadelede orman ve ilişkili ekosistemlerin kritik rolü: karbon depolama ve su üretimi. İklim Değişikliği ve Kalkınma. Sayfa: 104-125.

Serengil, Y., Swank, W.T., Vose, J.M., 2012. Alterations on flow variability due to converting hardwood forests to pine. iForest, 5: 44-49.

Serengil, Y., Gökbulak, F., İnan, M., Özcan, M., 20072010. Kentsel Havzalar için GIS tabanlı Basit bir Kanal Duyarlılığı Tahmin Modelinin Geliştirilmesi. TÜBİTAK 107Y149 nolu ÇAYDAG Projesi.

Serengil, Y., Sengönül, K., Uzun, A., Erdem, N., İnan, 
M., Yurtseven, İ., Tekin, H., 2012-2015. sürdürülebilir arazi planlama çalışmalarını destekleyecek bir iklim değişikliği-ekosistem hizmetleri yazılımının geliştirilmesi. TÜBITTAK 112 Y096 nolu ÇAYDAG Projesi.

Serengil, Y., Yaşar, S., Yurtseven, İ., Randhir, T., Kalın, L.; Pamukçu Albers., 2018-2021. Bütünleşik Havza Yönetim Planlarına Hidro-Ekolojik Katkı Sağlayacak, Ülkemize Özgü Bir Akarsu Koridoru Etüt Metodunun Geliştirilmesi ve Yaygınlaştırılması. TÜBİTAK 116 Y446 nolu 1003 Öncelikli Alanlar Ar-Ge Projesi.

Sicard, P., Augustaitis, A., Belyazid, S., Calfapietra, C., de Marco, A., Fenn, M., Bytnerowicz, A., Grulke, N., He, S., Matyssek, R., Serengil, Y., Wieser, G., Paoletti, E., 2016. Global topics and novel approaches in the study of air pollution, climate change and forest ecosystems. Environmental Pollution, 213: 977-987.

SKKY, 2004. Su Kirliliği Yönetmeliği. Resmî Gazete Tarihi: 31.12.2004 Resmî Gazete Sayısı: 25687.

Stankey, George H.; Clark, Roger N.; Bormann, Bernard T. 2005. Adaptive management of natural resources: theory, concepts, and management institutions. Gen. Tech. Rep. PNW-GTR-654. Portland, OR: U.S. Department of Agriculture, Forest Service, Pacific Northwest Research Station. $73 \mathrm{p}$.

Walkley, A.; Black, I.A. 1934. An examination of Degtjareff method for determining soil organic matter, and proposed modification of the chromic acid tritation method. Soil Science, 37: 29-38. 